\title{
The effect of drought on energy and water vapour exchange above a mediterranean C3/C4 grassland in Southern Portugal
}

\author{
L.M. Aires ${ }^{a, *}$, C.A. Pio ${ }^{a}$, J.S. Pereira ${ }^{b}$ \\ ${ }^{a}$ CESAM \& Departamento de Ambiente e Ordenamento, Universidade de Aveiro, Campus de Santiago, 3810-193 Aveiro, Portugal \\ ${ }^{\mathrm{b}}$ Departamento de Engenharia Florestal, Instituto Superior de Agronomia, Tapada da Ajuda, 1349-017 Lisboa, Portugal
}

\section{A R T I C L E I N F O}

Article history:

Received 13 March 2007

Received in revised form

3 November 2007

Accepted 6 November 2007

Keywords:

Mediterranean grassland

Eddy covariance

Energy partitioning

Evapotranspiration

Drought

Surface conductance

Decoupling coefficient

\begin{abstract}
A B S T R A C T
We studied the seasonal and interannual variation in surface energy fluxes - net radiation $\left(R_{n}\right)$, soil heat $(G)$, sensible heat $(H)$ and latent heat $(\lambda E)$ fluxes - and water vapour exchange above a Mediterranean C3/C4 grassland in Portugal, during two hydrological years, i.e., the period from 1 October to 30 September of the next year, of contrasting rainfall. The first year, 2004-2005, was dry, with total precipitation $45 \%$ below the long-term mean $(669 \mathrm{~mm})$, whereas the following, 2005-2006, was normal, with total precipitation only $12 \%$ above the long-term mean. Soil water availability and plant canopy growth were the most important factors in determining the seasonal and interannual variation in energy partitioning. During autumn, winter and early spring the ratio $\lambda E / R_{n}$ dominated over $H / R_{n}$, in the two years of the study, whereas on an annual basis, the major portion of $R_{n}$ was consumed in $H$ and $\lambda E$ in the dry and normal years, respectively. The total annual evapotranspiration $(E)$ and its daily maximum were $316 \mathrm{~mm}$ and $2.8 \mathrm{~mm}$ per day, respectively, for the dry year, and $481 \mathrm{~mm}$ and $4.5 \mathrm{~mm}$ per day for the normal year. After the senescence of the C3 species, the warm-season perennial C4 grass, Cynodon dactylon L., played a preponderant role in maintaining substantial $E$ rates contributing to soil water depletion. In this study, we assessed the effects of the most relevant biophysical factors on surface conductance $\left(g_{\mathrm{s}}\right)$ and $\mathrm{E}$. We found that the Priestley-Taylor coefficient and $g_{\mathrm{s}}$ were substantially reduced when the average volumetric soil moisture content in the top $15 \mathrm{~cm}$ of the soil profile dropped below $14 \%$. With abundant soil moisture and leaf area index (LAI) greater than 1, the evaporative fractions $\left(\lambda E / R_{n}\right)$ were linearly related to LAI $\left(R^{2}=0.73\right)$. The decoupling coefficient $(\Omega)$ ranged from a maximum of about 0.7 , under non-limiting soil moisture conditions, to a minimum of about 0.1 , under soil moisture deficit. This suggests that $E$ was strongly controlled by the vapour pressure deficit of the air and $g_{\mathrm{s}}$ during the periods with limiting soil moisture.
\end{abstract}

(C) 2007 Elsevier B.V. All rights reserved.

\section{Introduction}

The terrestrial surface energy balance is influenced by vegetation and drives not only the local, but also the regional and global climate (Raupach, 1998; Zeng and Neelin, 2000). Grasslands play an important role in the exchange of water vapour and energy between the biosphere and the atmosphere as they comprise about one third of the word's area of natural vegetation (Adams et al., 1990). In Portugal, grasslands cover about $15 \%$ of the territory, largely in the south, where a Mediterranean type of climate prevails. Climate change scenarios for the Mediterranean region, and especially for Portugal, suggest an increase in mean air temperature and more frequent and prolonged droughts (Miranda et al., 2002). There is therefore value in understanding how climate variability, particularly reductions in precipitation and shifts in its seasonality, influences energy

\footnotetext{
* Corresponding author. Tel.: +351 234 370200; fax: +351234 370309.

E-mail address: laires@dao.ua.pt (L.M. Aires).
} 
partitioning in Mediterranean grasslands, not only to improve our knowledge of the mechanisms that control energy and water fluxes, but also to anticipate possible impacts of the climate change scenarios and to give the modellers a better basis to improve and validate their models.

Water and energy exchanges on seasonal and/or annual time scales have been documented for temperate C3/C4 grasslands (Burba and Verma, 2001, 2005; Meyers, 2001; Wever et al., 2002) and semi-arid C3/C4 grasslands (Li et al., 2006). In Mediterranean ecosystems, only Baldocchi et al. (2004) have reported continuous measurements of water and energy fluxes from an annual grassland with a C3 plant community. However, there is a lack of information on how a mixture of $\mathrm{C} 3 / \mathrm{C} 4$ species influences the water and energy exchanges in Mediterranean climates.

Whereas Mediterranean C3 grasslands are dominated by annual plants and have no vegetation during the dry season, the presence of warm-season C4 species allows C3/C4 grasslands to remain active during most of the summer. In Southern Portugal, Bermuda Grass (Cynodon dactylon L.) is an invasive species in some of the semi-natural grasslands. This perennial C4 plant prospers mainly late in the season and has been shown to be relatively drought-tolerant and deep-rooted, concentrating about $40 \%$ of the root biomass in the top $20-25 \mathrm{~cm}$ below the soil surface (Huang et al., 1997; Mamolos et al., 2001; Vignolio et al., 2005). The length and area of its root system increase under water deficits (Vignolio et al., 2002), thus enhancing the capability to absorb water from deeper soil horizons. For example, in the conditions of Mediterranean climate, Mamolos et al. (2001) found that the abundance of C. dactylon increased in the field, even at very low values of soil matric potential in the upper soil layer. Thus, compared with Mediterranean C3 grasslands, C3/C4 grasslands may have higher evapotranspiration during the summer, thus enhancing soil water depletion.

The objectives of this investigation were to (1) examine and quantify the seasonal and interannual variation in energy and water vapour exchange and (2) assess the response of surface conductance and evapotranspiration to changes in the most relevant physical and physiological factors. As it turned out, precipitation in the period of measurement, between 2004 and 2006, varied substantially: the hydrological year (i.e., the period from 1 October to 30 September of the next year) of 2004-2005 was very dry, whereas 2005-2006 was normal. In fact, the water deficits during 2004-2005 - the driest episode in the last 140 years in western Iberia - strongly affected negatively gross primary production (Pereira et al., 2007). This allowed us to investigate further the effects of drought on water vapour fluxes and energy partitioning in a Mediterranean grassland.

\section{Material and methods}

\subsection{Site description}

The study area is a semi-natural grassland located in Monte do Tojal, Évora, in Southern Portugal ( $38^{\circ} 28^{\prime} 28^{\prime \prime} \mathrm{N} ; 8^{\circ} 01^{\prime} 25^{\prime \prime} \mathrm{W}$; $190 \mathrm{~m}$ a.s.l.) and was established in June of 2004 as a part of the Carboeurope IP project.

The soil is a Luvisol (FAO), containing $20 \%$ clay, $71 \%$ sand and $9 \%$ silt, and overlays a fractured rock. The soil profile (about $90 \mathrm{~cm}$ deep) presents a relatively dense layer of clay between 25 and $50 \mathrm{~cm}$ depth. The bulk density of the upper $30 \mathrm{~cm}$ of the soil profile is around $1640 \pm 80 \mathrm{~kg} \mathrm{~m}^{-3}(n=16)$.

The climate is Mediterranean with hot, dry summers and mild, wet winters. Long-term (1951-1980) mean annual air temperature and mean annual precipitation are $15.5^{\circ} \mathrm{C}$ and $669 \mathrm{~mm}$, respectively (INMG, 1991). The study was conducted between 2004 and 2006 and analyzed in hydrological years: 2004-2005 from day of the year (DOY) 275 in 2004 to DOY 273 of 2005 ; 2005-2006 from DOY 274 in 2005 to DOY 273 of 2006. These periods correspond approximately to the annual cycle of the vegetation.

The dominant herbaceous species at the site are annuals (cold-season C3 grasses). As often occurs the native plant community has been invaded by a warm-season perennial C4 grass, C. dactylon (L.) Pers. The C3 grassland community was dominated by Avena barbata Link subsp. Lusitanica (Tab. Mor.) Romero Zarco, Vulpia bromoides (L.) S.F. Gray, Vulpia geniculata (L.) Link, Medicago sativa L., Medicago polymorpha L., Trifolium resupinatum L., Trifolium subterraneum L., Ornithopus compressus L., Chamaemelum mixtum (L.) All., Parentucellia viscosa (L.) Caruel and Crepis vesicaria L. The C3 grassland community began to grow with the first rain events in autumn and senesced by about midspring. Shoots of the C4 grass began growth in late winter and died-out in early autumn. The whole area within the tower footprint was normally grazed during the autumn and early winter, one or two times per week with a stocking density of 60 sheep/ha.

\subsection{Field measurements}

The water vapour and sensible heat fluxes were continuously measured using an eddy covariance system at a height of $2.5 \mathrm{~m}$. The system consisted of a 3D sonic anemometer (model 1210R3, Gill Instruments Ltd., Lymington, UK) and an openpath infrared gas analyzer (IRGA, model LI-7500, LI-COR Inc., Lincoln, NE, USA) to measure the three components of the wind velocity, the sonic temperature and the densities of water vapour and $\mathrm{CO}_{2}$, respectively. The IRGA was placed with a $30^{\circ}$ tilt angle to minimize accumulation of dust and water droplets on the windows. Calibration of the IRGA was done once a month using nitrogen gas and $350 \mathrm{ppm} \mathrm{CO}_{2}$ gas to calibrate the $\mathrm{CO}_{2}$ and water vapour zeros and the span of $\mathrm{CO}_{2}$, respectively. The span of water vapour was calibrated with dew point values estimated from air temperature and relative humidity, using conventional physical formulations. Realtime data were acquired at $20 \mathrm{~Hz}$ sampling rate using the software Eddymeas (Meteotools, Jena, Germany) and stored on a laptop computer for later processing.

Continuous measurements also included standard climatological and soil parameters. Air temperature and relative humidity were measured at the height of $1.5 \mathrm{~m}$ with a temperature/humidity probe (MP300, Campbell Scientific Ltd., Shepshed, UK). The all-wave radiation components, incoming and outgoing longwave radiation (CG-3, Kipp \& Zonen, Delft, $\mathrm{NL}$ ), incoming shortwave radiation (Casella solarimeter, Casella London Ltd., Kempston, UK) and outgoing shortwave radiation (Starpyranometer 8101, Philipp Schenk, Wien, AT) were also measured at the height of $1.5 \mathrm{~m}$. Longwave radiation was only measured from January 2005 onwards. Soil temperature at the 
depths of 2, 10 and $20 \mathrm{~cm}$ was measured by Platinum Resistance Thermometers. One soil heat flux plate (HFT-3, Campbell Scientific Ltd., Shepshed, UK) was buried at the depth of $8 \mathrm{~cm}$ and the soil heat storage above the plate was added to the final calculation of the soil heat flux. Soil volumetric water content at depths of 2, 15 and $30 \mathrm{~cm}$ was measured using frequency domain reflectometer probes (ML2x, Delta-T Devices, Burwell, Cambridge, UK). Precipitation was measured with a tipping bucket raingauge (ARG100, Environmental Measurements Ltd., Gateshead, UK). The output signals of the equipment above were scanned by a data-logger (DT-605, Datataker Ltd., Cambridge, UK) and the 30-min averages were subsequently sent and stored on a laptop computer.

Leaf area index (LAI) was determined at about 1-month intervals from April 2005 to September 2006. However, during the period of fast plant growth the sampling frequency was increased to about twice per month. On each sampling date, six patches each of $0.063 \mathrm{~m}^{2}$ area were harvested and the green leaves were removed from the stems. In the laboratory, the green leaves were scanned using a common scanner and the area was determined by appropriate software (Sigmascan, Systat Software UK Ltd., London, UK).

Aboveground biomass was also determined using generally the same material that had been harvested for the LAI determination. The green plant parts were separated from the dead plant material and their biomass was determined gravimetrically after the samples had been dried for $72 \mathrm{~h}$ at $65^{\circ} \mathrm{C}$. The total aboveground biomass was hence calculated.

\subsection{Data processing and flux computation}

The half-hourly fluxes of sensible heat $(H)$ and water vapour $(E)$ were determined by the eddy covariance method as follows (e.g., Fuehrer and Friehe, 2002):

$H=\rho C_{P} \overline{w^{\prime} T^{\prime}}$

$E=\overline{w^{\prime} \rho_{\mathrm{v}}^{\prime}}$

where $\rho$ is the mean air volumic mass $\left(\mathrm{kg} \mathrm{m}^{-3}\right), C_{P}$ is the specific heat capacity of the air at constant pressure $\left(\mathrm{J} \mathrm{kg}{ }^{-1} \mathrm{~K}^{-1}\right), w^{\prime}$ is the fluctuation of the vertical wind speed $\left(\mathrm{m} \mathrm{s}^{-1}\right), \mathrm{T}^{\prime}$ is the fluctuation of temperature $(\mathrm{K})$ and $\rho_{\mathrm{v}}^{\prime}$ is the fluctuation of water vapour volumic mass $\left(\mathrm{mmol} \mathrm{m}^{-3}\right)$. The overbars denote time averaging. The latent heat flux $(\lambda E)$ was then calculated by multiplying the water vapour flux by the latent heat of vaporization of water $(\lambda)$ and the water molecular mass. These calculations included coordinate rotation 2D, spikes detection and removal similar to Vickers and Mahrt (1997) and check for instantaneous records exceeding realistic absolute limits. In addition, sensible heat fluxes were corrected for humidity fluctuations (Liu et al., 2001) and the air density fluctuations were taken into account to correct the fluxes of water vapour (Webb et al., 1980).

\subsection{Data quality control and gap-filling}

The available data sets were screened to remove any anomalous half-hourly fluxes that resulted from malfunction of the sensors. First, using an approach similar to Rogiers et al.
(2005), the fluxes of water vapour were discharged whenever the measured $\mathrm{H}_{2} \mathrm{O}$ concentration differed by more than $30 \%$ from that estimated from relative humidity data, using conventional physical formulations. Those cases were related to periods when rain, dew, dust, birds using the instrument as a roost caused significant interference to the optical path of the open-path analyzer. Second, the fluxes of water vapour were excluded if the removed spikes or the absolute limit violations exceeded $1 \%$ of the total records of any of the three components of wind velocity and/or $\mathrm{H}_{2} \mathrm{O}$ concentration; sensible heat fluxes were also filtered using a similar reasoning for the three components of wind velocity and/or sonic temperature.

After this filtering process, the remaining data sets of sensible heat and water vapour fluxes were subsequently submitted to data quality tests, the integral turbulence characteristics and stationarity tests (Foken and Wichura, 1996). Whenever the mean covariance of six intervals of a time series deviated by more than $50 \%$ of the value of the covariance for the full period, the mean flux was considered non-stationary and hence excluded from the analysis. The integral characteristics of the vertical wind $\left(\sigma_{\mathrm{w}} / u^{*}\right)$ were assessed to test the development of turbulent conditions. Thus, if the measured value deviated by more than $50 \%$ of the modelled result, the turbulence was not considered well developed and the mean flux was removed. Data gaps during the whole study period, due to missing and rejected data, were about $40 \%$ and $26 \%$ for water vapour and sensible heat flux, respectively. In both cases, around $70 \%$ of the total data gaps occurred during nocturnal periods.

In this study, we examined the energy balance closure which is considered an independent method to assess the reliability of the eddy covariance measurements (Wilson et al., 2002). For short vegetation, the energy balance closure can be written as (e.g., Kato et al., 2004; Li et al., 2006):

$H+\lambda E=R_{n}-G$

where $R_{n}$ and $G$ are the net radiation and the soil heat flux, respectively. After performing a linear regression between the eddy fluxes $(H+\lambda E)$ and the available energy $\left(R_{n}-G\right)$, using halfhourly values, the intercept, slope and coefficient of determination $\left(R^{2}\right)$ for the year 2005 were $11.47 \mathrm{~W} \mathrm{~m}^{-2}, 0.81$ and 0.95 $(P<0.0001)$, respectively. These results suggest that the eddy covariance measurements underestimated $H+\lambda E$ by $19 \%$. A slight degradation (1\%) in the energy balance closure was observed during 2006. Although, the energy balance closure is not perfect, it is within the normal range found in most studies. Several reasons have been put forward to explain the energy imbalance (Twine et al., 2000; Wilson et al., 2002), but identifying and quantifying all its sources is rather difficult. For the case of this study, part of the imbalance may be related to the measurements/estimations of $H$ and $\lambda E$. For example, we did not apply an angle-of-attack dependent calibration for the sonic anemometer, which has been shown to increase $H$ and $\lambda E$ by about $5 \%$ for smooth canopies (see van der Molen et al., 2004). The remainder of the imbalance is, however, believed to be related to the measurements of $R_{n}$ and $G$. We used only one soil heat flux plate, which is likely to be too small a sample as $G$ is expected to vary with location on the ground. Moreover, the fact 
that the vegetation in the measurement point of $R_{n}$ and $G$ was slightly higher and denser (the area was fenced and thus not affected by grazing) is also expected to explain some of the imbalance because $R_{n}-G$ tend to be higher in such conditions (see Bremer et al., 2001). However, using daily values (where $G$ is close to zero) in the regression for the whole study period, the energy imbalance decreased to $12 \%$. Also, the energy balance ratio (EBR) (Wilson et al., 2002) for the whole study period indicated a lower underestimation $(\mathrm{EBR}=0.87)$.

To evaluate the contribution of the study area to the total flux measured by the eddy covariance system, the forward Lagrangian stochastic trajectory model by Rannik et al. (2003) was used. The approach for site evaluation is described in Gockede et al. (2006). Even using a conservative vegetation height $(0.05 \mathrm{~m})$ as input, the results showed that for all atmospheric stability conditions the measurements were representative of the area intended to be observed.

Complete data sets of sensible heat and water vapour fluxes were created using various gap-filling approaches. Missing time periods of water vapour were filled following the methodology proposed by Reichstein et al. (2005) and missing sensible heat flux measurements were replaced using the method of mean diurnal variation (Falge et al., 2001). Gaps in the incoming components of radiation, temperature and precipitation data were filled with data from a nearby meteorological station. Because we did not perform measurements of longwave radiation during the last months of $2004, R_{n}$ was not determined. Thus, for this period, $R_{n}$ was modelled using Eq. (3), including the energy imbalance (assuming that it was equivalently distributed between $R_{n}$ and $G$ ).

\subsection{Data analysis}

Daily potential evapotranspiration $\left(E_{\mathrm{P}}\right)$ was estimated by the Penman-Monteith combination equation (Monteith, 1965):

$\lambda E_{\mathrm{P}}=\frac{\Delta\left(R_{\mathrm{n}}-G\right)+\rho C_{\mathrm{P}} D / r_{\mathrm{a}}}{\Delta+\gamma\left(1+r_{\mathrm{s}} / r_{\mathrm{a}}\right)}$

where $\Delta$ is the rate of change of saturation vapour pressure with temperature $\left(\mathrm{kPa} \mathrm{K}^{-1}\right)$, $D$ is the vapour pressure deficit $(\mathrm{kPa}), r_{\mathrm{a}}$ is the aerodynamic resistance $\left(\mathrm{d} \mathrm{m}^{-1}\right), \gamma$ is the psychometric constant $\left(\mathrm{kPa} \mathrm{K}^{-1}\right)$ and $r_{\mathrm{s}}$ is the surface resistance $\left(\mathrm{d} \mathrm{m}^{-1}\right)$. The measured available energy $\left(R_{n}-G\right)$ was converted to $\mathrm{MJ} \mathrm{m}{ }^{-2} \mathrm{~d}^{-1}$. Calculations of $\Delta, \rho\left(\mathrm{kg} \mathrm{m}^{-3}\right), \mathrm{C}_{\mathrm{P}}\left(\mathrm{MJ} \mathrm{kg}^{-1} \mathrm{~K}^{-1}\right), \mathrm{D}, \gamma$ and $r_{\mathrm{a}}$ were performed following Allen et al. (1998). To determine the aerodynamic resistance, the seasonal changes in canopy height were accounted for. The surface resistance was assumed to be $70 \mathrm{~s} \mathrm{~m}^{-1}$, the FAO/Allen value for a grass reference crop under well-watered conditions (Allen et al., 1998).

In order to calculate the daily values of the Priestley-Taylor coefficient $\left(\lambda E / \lambda E_{\text {eq }}\right)$, the equilibrium latent heat flux $\left(\lambda E_{\text {eq }}\right)$ was determined using Eq. (5) (Priestley and Taylor, 1972):

$\lambda E_{\mathrm{eq}}=\frac{\Delta\left(R_{\mathrm{n}}-\mathrm{G}\right)}{\Delta+\gamma}$

To assess the physiological control of the water exchange between the ecosystem and atmosphere, half-hourly surface conductance $\left(g_{\mathrm{s}}\right)$ was calculated by inverting Eq. (4). Aerody- namic conductance $\left(g_{\mathrm{a}}\right)$ was obtained from sonic anemometer outputs as (Monteith and Unsworth, 1990):

$\frac{1}{g_{\mathrm{a}}}=\frac{u}{u_{*}^{2}}+6.2 u_{*}^{-0.67}$

where $u^{*}$ is the friction velocity $\left(\mathrm{m} \mathrm{s}^{-1}\right)$ and $u$ is the mean wind speed $\left(\mathrm{m} \mathrm{s}^{-1}\right)$. Daily values of $g_{\mathrm{s}}$ were derived from the average of daytime observations, as an indicator of daytime surface conductance. Conductances in $\mathrm{m} \mathrm{s}^{-1}$ were converted to $\mathrm{mmol} \mathrm{m} \mathrm{m}^{-2} \mathrm{~s}^{-1}$ using the ideal gas law.

The coupling between the ecosystem surface and the atmospheric boundary layer was estimated through the decoupling coefficient $(\Omega)$, calculated on a half-hourly basis according to Jarvis and McNaughton (1986):

$\Omega=\frac{(\Delta+\gamma)}{\Delta+\gamma\left(1+g_{\mathrm{a}} / g_{\mathrm{s}}\right)}$

Daily values of decoupling coefficient were also obtained by averaging all daytime observations.

\section{Results and discussion}

\subsection{Meteorology, leaf area index and aboveground biomass}

The variations of the major environmental conditions and plant parameters during the two hydrological years are shown in Fig. 1. The seasonal pattern of the daily-integrated shortwave radiation $\left(R_{s}\right)$ was similar in the two hydrological years, with minimum values $\left(1-5 \mathrm{MJ} \mathrm{m}^{-2} \mathrm{~d}^{-1}\right)$ in cloudy winter days and maximum values (around $30 \mathrm{MJ} \mathrm{m}^{-2} \mathrm{~d}^{-1}$ ) in the summer. The number of cloudy days was clearly lower in 2005, especially between the days of the year 1 and 60 . Along with $R_{\mathrm{s}}$, maximum air temperatures $\left(T_{\max }\right)$ varied from 10 to $15^{\circ} \mathrm{C}$, in the winter, to extreme values (above $35^{\circ} \mathrm{C}$ ), during the summer. The minimum air temperatures $\left(T_{\min }\right)$ reached $c a .-5{ }^{\circ} \mathrm{C}$ in winter, whereas $T_{\text {min }}$ in summer was consistently well above $10^{\circ} \mathrm{C}$. The mean air temperature for the hydrological years of 2004-2005 and 2005-2006 was 14.7 and $14.5^{\circ} \mathrm{C}$, respectively.

Precipitation differed markedly between the two hydrological years, in both the amounts and the patterns of rain. The first hydrological year was dry, with $364 \mathrm{~mm}$ of total precipitation (45\% below the long-term mean) and the second was normal, with $751 \mathrm{~mm}$ of total precipitation (only $12 \%$ above the long-term mean). A long period, from DOY 340 to 80 , without significant rainfall, occurred during the dry hydrological year of 2004-2005 (Fig. 1g-h). This led to severe plant water deficits by late winter as the soil moisture content dropped below 10\% in the upper $15 \mathrm{~cm}$ soil layer. In contrast, precipitation was uniformly distributed during both the winter and early spring periods of the normal year (20052006), leading to high soil moisture levels (Fig. 1h-i). Isolated rain events during late spring and summer periods led to short-term peaks in soil moisture. Large rain events in late spring of 2006 combined with a subsequent rain pulse during the summer (Fig. 1i) led to consistently higher soil moisture than in the previous summer. It is important to mention that 


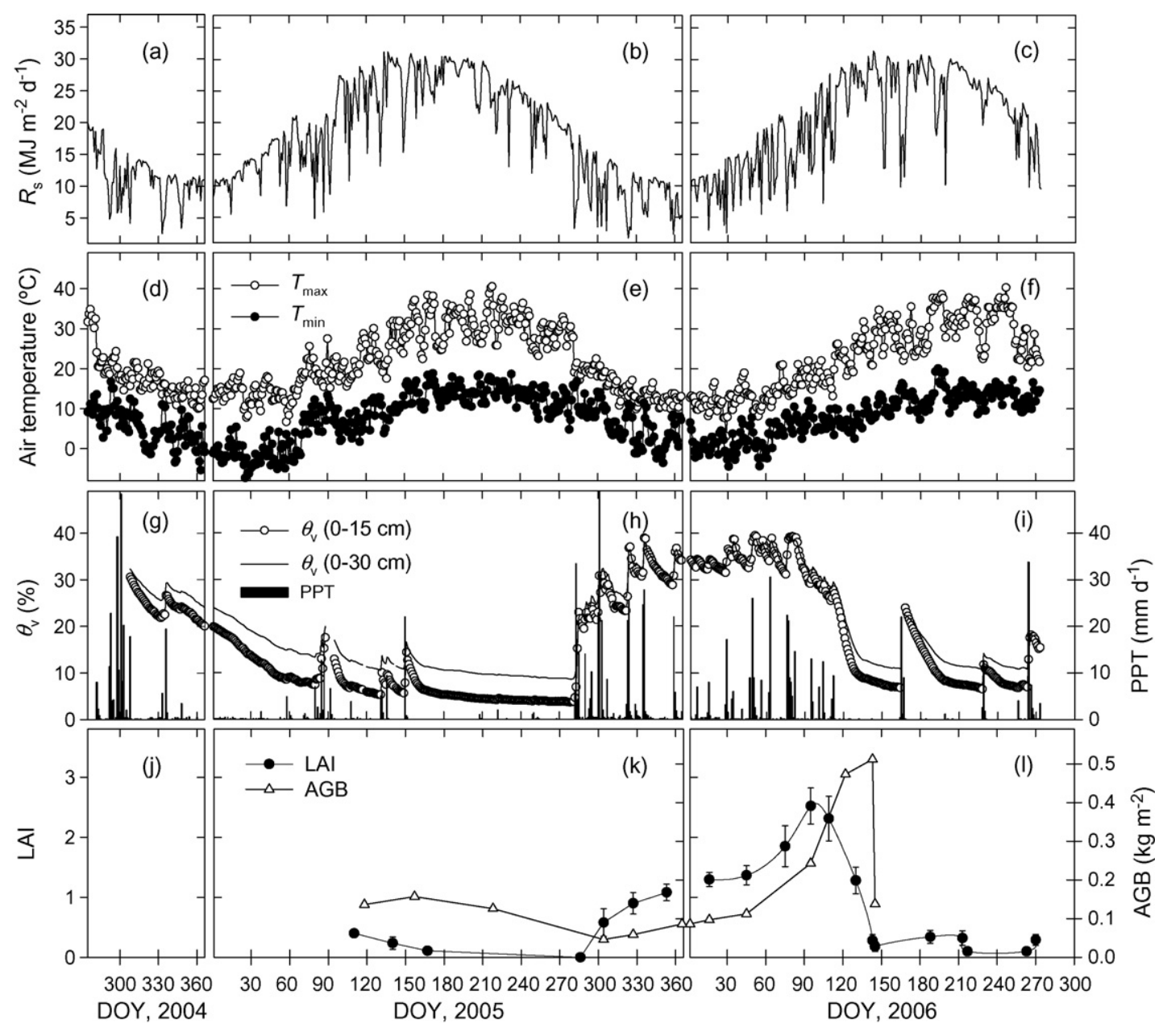

Fig. 1 - Seasonal variation in (a-c) daily-integrated shortwave radiation $\left(R_{s}\right)$, (d-f) daily maximum ( $\left.T_{\text {max }}\right)$ and daily minimum $\left(T_{\mathrm{min}}\right)$ air temperature, $(\mathrm{g}-\mathrm{i})$ daily total precipitation (PPT) and averaged volumetric soil moisture content $\left(\theta_{\mathrm{v}}\right)$ from the upper $(0-15 \mathrm{~cm})$ and $(0-30 \mathrm{~cm})$ of soil and $(j-1)$ mean green leaf area index (LAI) \pm S.E. and dry aboveground biomass (AGB) over the course of the study. DOY means day of year.

the higher soil moisture levels of the upper $30 \mathrm{~cm}$ soil layer (Fig. 1g-i), especially during the water-stressed periods, showed the capability of this soil to hold water at the depth of $30 \mathrm{~cm}$, where a relatively dense layer of clay is present. In fact, even during the summer, the soil moisture at $30 \mathrm{~cm}$ depth did not drop below $18 \%$.

There was a clear difference in grass production between hydrological years (Fig. 1j-l). Overall, LAI and aboveground biomass responded well to the variations in soil moisture and temperature. Maximum standing biomass was only $0.157 \mathrm{~kg} \mathrm{~m}^{-2}$ during the dry year (2004-2005) (Fig. 1k), but reached a maximum value of $0.512 \mathrm{~kg} \mathrm{~m}^{-2}$ during the normal year (2005-2006) (Fig. 11). Hence, the LAI at the peak growth period averaged 0.4 and 2.5 in the dry and normal years, respectively. Although measurements of LAI were not performed before April 2005, LAI probably did not reach values above 1 because of low soil moisture in combination with winter grazing. The maximum LAI of the dry year laid within a range of values published for semi-arid grasslands (e.g., Li et al., 2006), while for the normal year the maximum LAI was similar to those observed in an Mediterranean annual grassland in California (Baldocchi et al., 2004).In both hydrological years, the end of the senescence of the C3 grasses occurred by the beginning of May (ca. DOY 132). Thereafter, the warm-season C4 grass, C. dactylon L., remained green but with highly variable LAI. In 2005, the LAI of the C4 grass between DOY 132 and 170 was above 0.1 , but then decreased smoothly to approach zero at the end of the summer (Fig. 1k). In contrast, in 2006, the grass was cut on DOY 144, reducing the LAI of the C4 grass from ca. 0.3 to 0.15 (Fig. 1l). The hay was left on the ground partially covering the green leaves until DOY 162, when it was finally removed. Although, we did not measure the effect of hay coverage, the LAI of uncovered green leaves would be slightly lower than 0.15 . On the DOY 163, a strong rain pulse led to a quick development of the C4 grass but the amount of rain was not enough to allow germination and support growth of C3 annuals. On DOY 188, the LAI of the C4 grass was 0.35 and remained almost constant until DOY 213. Thereafter, several grazing events gradually reduced its value to about 0.1 , on DOY 217. An increase in LAI was observed again on DOY 270 (beginning of autumn), because the previous heavy rain promoted the C3 grass seed 


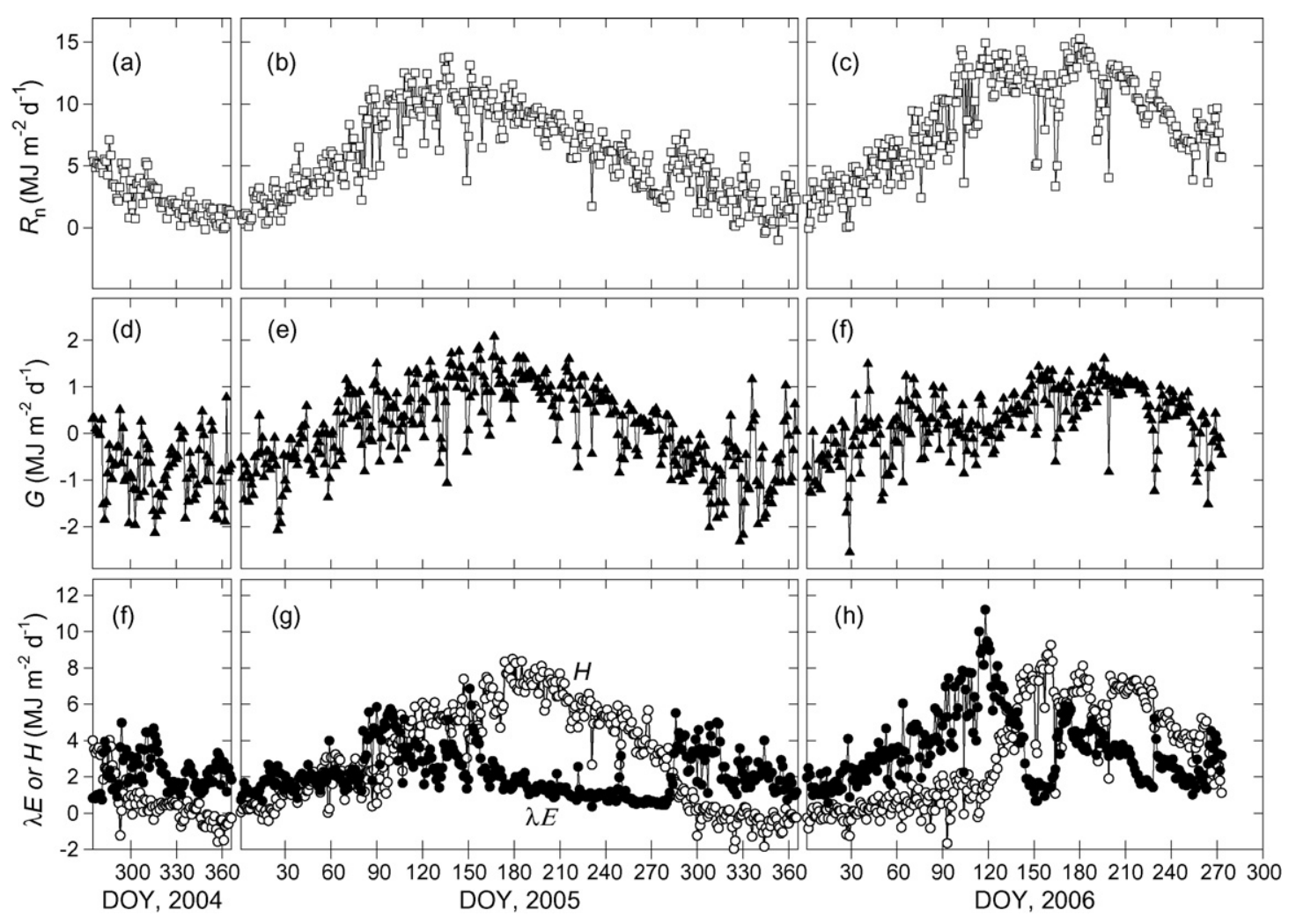

Fig. 2 - Seasonal pattern of $(a-c)$ daily-integrated net radiation flux $\left(R_{n}\right),(d-f)$ soil heat flux $(G)$ and $(g-i)$ sensible heat flux $(H)$ and latent heat flux $(\lambda E)$ during the course of the study.

germination, starting a new cycle of the annual C3 grasses. The lower temperatures in the beginning of autumn in combination with the competition from the C3 grasses, led to the death of the aboveground parts of the $\mathrm{C} 4$ grass.

\subsection{Seasonal and interannual variation in energy fluxes}

Fig. 2 shows the seasonal variation in energy fluxes over the course of the study. The seasonal pattern of $R_{\mathrm{n}}$ followed closely the variation of $R_{\mathrm{s}}$ (Fig. 1a-c), showing maximum values $\left(10-15 \mathrm{MJ} \mathrm{m}^{-2} \mathrm{~d}^{-1}\right)$ in the summer and minimum values, close to zero, in late autumn and early winter. Daily $G$ (Fig. 2d-f) was generally negative in autumn and winter, indicating an important loss of energy from the soil to the atmosphere. In spring and summer, it was predominantly positive, except for most cloudy days. The temporal variation of $H$ was concomitant with the pattern of change of $R_{n}$. In late autumn and winter, $\mathrm{H}$ was close to zero, often negative, but increased afterwards to daily values above $8 \mathrm{MJ} \mathrm{m}^{-2}$ in the summer (Fig. $2 \mathrm{~g}-\mathrm{i}$ ). The negative values of $\mathrm{H}$ reflected the transfer of heat from the atmosphere to the ecosystem.

The minimum daily values of $\lambda E\left(1-2 \mathrm{MJ} \mathrm{m}^{-2}\right)$ were recorded during both winters, essentially due to low atmospheric evaporative demand. However, in spring and summer the rates of $\lambda E$ were clearly controlled by the soil moisture conditions and canopy growth. Therefore, the drought conditions in late winter and early spring of 2005 led the ecosystem to transfer $\lambda E$ at a maximum rate of about $6 \mathrm{MJ} \mathrm{m}^{-2}$ per day, which was approximately half of the maximum rate observed in $2006\left(11 \mathrm{MJ} \mathrm{m}^{-2} \mathrm{~d}^{-1}\right)$ with abundant soil moisture and a denser canopy. In the summer of 2006, higher soil moisture, in combination with higher LAI, resulted in consistently greater $\lambda E$ than in the previous summer.

In both hydrological years, $H$ switched to $\lambda E$ by about the first rain events that increased soil moisture and consequently propitiated seed germination of the C3 community. The switch from $\lambda E$ to $H$ occurred at the same time as the senescence of the C3 herbaceous species. Similar changes, essentially associated with the variation in soil moisture, were also observed in a Mediterranean grassland in California (Valentini et al., 1995) and in a temperate grassland in Canada (Wever et al., 2002).

The seasonal and interannual differences in energy fluxes were largely imposed by the variability in soil moisture and canopy growth. To better understand these differences, we divided each hydrological year into three main periods of growth (Table 1). Pre-growth was defined as the period between 1 October and 31 December, when the C3 grasses germinated, began to grow, but remained short. The Growth period, when maximum plant growth was observed, occurred between 1 January and the end of the C3 plant senescence (12 May, DOY 132, in both hydrological years). The remaining period, until 30 September corresponding to the time when only the warm-season C4 species was present, was called Dry.

Soil water deficits combined with low LAI in the Growth and Dry periods of 2005 led to substantially lower cumulative $R_{n}$ values as compared with those from the same periods of 2006. This resulted in a considerable annual difference in $R_{n}$, 
Table 1 - Comparison of major meteorological and biometeorological parameters at different periods of growth for the two hydrological years

\begin{tabular}{|c|c|c|c|c|c|c|c|c|}
\hline & \multicolumn{8}{|c|}{ Period } \\
\hline & Pre-growth & Growth & Dry & Pre-growth & Growth & Dry & & \\
\hline & 2004 & 2005 & 2005 & 2005 & 2006 & 2006 & $\begin{array}{c}\text { 2004-2005 } \\
\text { hydrological } \\
\text { year }\end{array}$ & $\begin{array}{c}\text { 2005-2006 } \\
\text { hydrological } \\
\text { year }\end{array}$ \\
\hline $\mathrm{T}\left({ }^{\circ} \mathrm{C}\right)$ & 11.1 & 9.6 & 21.9 & 11.2 & 9.5 & 21.3 & 14.7 & 14.5 \\
\hline $\mathrm{T}_{\mathrm{s}}\left({ }^{\circ} \mathrm{C}\right)$ & 13.3 & 12.5 & 29.8 & 13.6 & 12.0 & 26.5 & 19.5 & 18.0 \\
\hline$R_{\mathrm{S}}\left(\mathrm{MJ} \mathrm{m}^{-2}\right)$ & 1048.0 & 2222.6 & 3585.2 & 939.4 & 2082.2 & 3452.8 & 6855.8 & 6474.4 \\
\hline $\mathrm{PPT}(\mathrm{mm})$ & 239.4 & 83.2 & 41.0 & 355.2 & 290.2 & 105.8 & 363.6 & 751.2 \\
\hline$\theta_{\mathrm{v}}(\%)$ & 24.1 & 10.8 & 5.3 & 26.0 & 31.1 & 10.1 & 10.9 & 21.8 \\
\hline $\mathrm{D}(\mathrm{kPa})$ & 0.35 & 0.42 & 1.52 & 0.32 & 0.25 & 1.36 & 0.83 & 0.69 \\
\hline$R_{n}\left(M J m^{-2}\right)$ & 235.2 & 775.7 & 1110.0 & 266.7 & 893.3 & 1455.1 & 2120.9 & 2615.1 \\
\hline$G\left(\mathrm{MJ} \mathrm{m}^{-2}\right)$ & -69.0 & -2.5 & 111.6 & -59.5 & -11.7 & 84.7 & 40.2 & 13.4 \\
\hline $\mathrm{H}\left(\mathrm{MJ} \mathrm{m} \mathrm{m}^{-2}\right)$ & 59.2 & 291.4 & 815.0 & 21.9 & 96.0 & 793.4 & 1165.7 & 911.4 \\
\hline$\lambda E\left(\mathrm{MJ} \mathrm{m}^{-2}\right)$ & 205.3 & 331.4 & 239.6 & 216.2 & 530.7 & 432.4 & 776.3 & 1179.3 \\
\hline$G / R_{n}$ & -0.29 & 0.00 & 0.10 & -0.22 & -0.01 & 0.06 & 0.02 & 0.01 \\
\hline$H / R_{n}$ & 0.25 & 0.38 & 0.73 & 0.08 & 0.11 & 0.55 & 0.55 & 0.35 \\
\hline$\lambda E / R_{n}$ & 0.87 & 0.43 & 0.22 & 0.81 & 0.59 & 0.30 & 0.37 & 0.45 \\
\hline$\beta=H / \lambda E$ & 0.49 & 0.89 & 4.54 & 0.45 & 0.12 & 2.31 & 2.20 & 1.05 \\
\hline$E(\mathrm{~mm})$ & 83.3 & 134.4 & 98.4 & 87.9 & 215.8 & 177.6 & 316.1 & 481.3 \\
\hline$E_{\mathrm{P}}(\mathrm{mm})$ & 128.3 & 292.7 & 739.8 & 133 & 263.2 & 675.2 & 1160.7 & 1071.4 \\
\hline$E_{\text {eq }}(\mathrm{mm})$ & 73.9 & 181.2 & 278.3 & 76.7 & 209.3 & 388.9 & 533.5 & 674.9 \\
\hline $\mathrm{E} / \mathrm{PPT}$ & 0.35 & 1.62 & 2.40 & 0.25 & 0.74 & 1.68 & 0.87 & 0.64 \\
\hline$E / E_{\text {eq }}$ & 1.13 & 0.74 & 0.35 & 1.15 & 1.03 & 0.46 & 0.59 & 0.71 \\
\hline $\mathrm{g}_{\mathrm{s}}\left(\mathrm{mmol} \mathrm{m} \mathrm{m}^{-2} \mathrm{~s}^{-1}\right)$ & 290.3 & 176.6 & 30.3 & 346.7 & 392.3 & 64.4 & 151.8 & 254.4 \\
\hline$\Omega$ & 0.53 & 0.38 & 0.12 & 0.56 & 0.59 & 0.21 & 0.33 & 0.44 \\
\hline
\end{tabular}

Pre-growth: period between 1 October and 31 December; Growth: period between 1 January and the end of the C3 species senescence (12 May, DOY 132, in both years); Dry: the remaining period until 30 September. Daily means for each period: $T$, air temperature; $T_{\mathrm{s}}$, soil temperature, averaged from the depth of 2, 10 and $20 \mathrm{~cm} ; \theta_{\mathrm{v}}$, volumetric soil moisture content, averaged from the upper $15 \mathrm{~cm}$ of soil; $D$, vapour pressure deficit; $\beta$, Bowen ratio; $g_{\mathrm{s}}$, surface conductance; $\Omega$, decoupling coefficient. Totals for each period: $R_{\mathrm{s}}$, shortwave radiation; PPT, precipitation; $R_{\mathrm{n}}$, net radiation; $G$, soil heat flux; $H$, sensible heat flux; $\lambda E$, latent heat flux, $E$, evapotranspiration; $E_{\mathrm{P}}$, potential evapotranspiration; $E_{\text {eq, }}$ equilibrium evapotranspiration.

2121 and $2615 \mathrm{MJ} \mathrm{m}^{-2}$ for the first and second hydrological years, respectively (Table 1$)$. Similar annual $R_{n}$ values were reported for a Mediterranean annual grassland in California (Baldocchi et al., 2004). Differently, a lower annual $R_{n}$ was observed for a semi-arid steppe in central Mongolia (Li et al., 2006) and higher values were found in a native tallgrass prairie in Oklahoma (Burba and Verma, 2005). Cumulative values of $G$, $H$ and $\lambda E$ are also summarized in Table 1.

The energy partitioning was different between the Growth periods and hydrological years (Table 1). The fraction $G / R_{n}$ increased from the pre-growth to the Dry period, in both hydrological years, but only reached the maximum of 0.1 in the Dry period of 2005 (Table 1). On an annual basis, the portion of $R_{n}$ consumed in $G$ was very low, 0.02 and 0.01 for the 2004-2005 and 2005-2006 hydrological years, respectively. A slightly higher, but small, annual fraction of 0.05 was reported by Li et al. (2006).

The fractions $\lambda E / R_{n}$ and $H / R_{n}$ varied inversely from the Pregrowth to the Dry periods (Table 1 ). Although in the Pre-growth and Growth periods the ratio of $\lambda E / R_{n}$ dominated over $H / R_{n}$, in the Dry periods the $H / R_{n}$ was dominant. The degree of dominance was substantially different for each hydrological year as reflected by the Bowen ratios (the ratios between $H$ and $\lambda E), \beta$ (Table 1). The major difference was found in the Growth and Dry periods, where $\beta$ varied from 0.89 to 4.54 , in the first hydrological year, and from 0.12 to 2.31, in the second, indicating higher soil water availability during 2006.
On an annual basis, the largest portion of $R_{n}$ was consumed in $H(0.55)$, in the first hydrological year, and in $\lambda E$ (0.45), in the second (Table 1). It is important to mention that the differences in energy closure between the two years may have introduced some uncertainties in the magnitude of the ratios of $\lambda E / R_{n}$ and $H / R_{n}$. Nevertheless, our results are within the expectable range, giving the contrasting climatological conditions observed. In this study, the annual ratios of $\lambda E / R_{n}$ (0.37 and 0.45) were lower than those reported by Burba and Verma (2005) for a native tallgrass prairie in Oklahoma, and higher than the ratio obtained by Li et al. (2006) for a semi-arid grassland.

The diurnal pattern of energy fluxes (Fig. 3) showed a distinct seasonal and interannual variation. As an example, we selected three periods of the main stages of plant growth; a period with relatively short vegetation (January, DOY 1-31), the period of maximum plant growth (April, DOY 91-120) and a period where the only plant species present was C. dactylon (July, DOY 182212). In 2005 and 2006, $R_{n}$ increased from values around $300 \mathrm{~W} \mathrm{~m}^{-2}$ in January (Fig. $3 \mathrm{a}$ and d) to values around $600 \mathrm{~W} \mathrm{~m}^{-2}$ in April (Fig. 3b and e). A further decrease occurred in July (Fig. 3c and f), but was less pronounced in 2006 than in 2005.

The partitioning of $R_{n}$ at midday differed markedly between the selected periods and years (Table 2). Even though the soil was fairly dry in January 2005 , the ratio $\lambda E / R_{n}$ was similar to that of January 2006, probably due to the low 


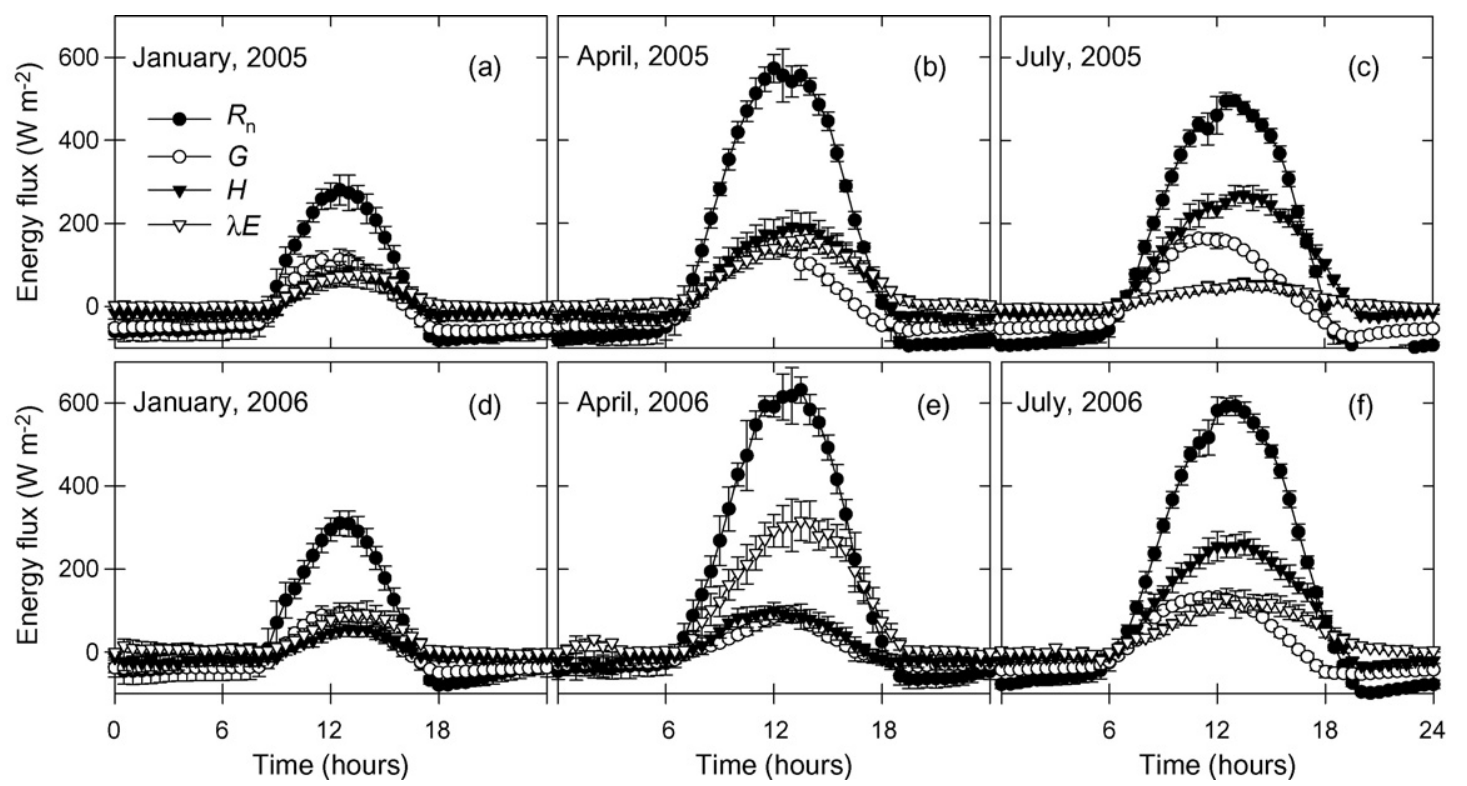

Fig. 3 - Seasonal and interannual variation in the mean diurnal course of net radiation flux $\left(R_{\mathrm{n}}\right)$, soil heat flux (G), sensible heat flux $(H)$ and latent heat flux $(\lambda E)$. (a and d) are shown a period with relatively short vegetation (January, DOY 1-31), (b and e) the period of maximum growth (April, DOY 91-120) and (c and f) a period where only the C4 species was present (July, DOY 182-212). The values represent half-hourly averages ( \pm S.E.) for cloudless and near-cloudless days. UTC time was used.

atmospheric evaporative demand in winter. However, the short canopy combined with low soil moisture and temperature meant that $G / R_{n}$ dominated in January 2005. Even in January 2006, the ratio $G / R_{n}$ shared the dominance with $\lambda E / R_{n}$. This reveals that $G$ was preponderant at midday during those periods. In a semi-arid steppe in central Mongolia, Li et al. (2006) also found that $G$ had a important role in energy partitioning at midday, due to the short canopy. In April 2005, very low soil moisture content, but higher amount of vegetation than in January, switched the dominance to $H / R_{n}$ (Table 2). In contrast, $\lambda E / R_{\mathrm{n}}$ strongly dominated in April 2006 as a consequence of the dense vegetation $(\mathrm{LAI}=2.5)$ and adequate soil moisture, which led to very low ratios of $H / R_{n}$ and $G / R_{n}$. With the reductions in soil moisture from April to July, $H / R_{n}$ was dominant in July of both years, but with increased importance of $\lambda E / R_{n}$ in July 2006 (Table 2).

Table 2 - Midday (10:00-15:00 h) partitioning components (soil heat $(G)$, sensible heat $(H)$ and latent heat $(\lambda E)$ fluxes) of $R_{n}$, maximum LAI and volumetric soil moisture content $\theta_{v}$, averaged from the upper $15 \mathrm{~cm}$ of soil, for the selected periods reported in Fig. 3

\begin{tabular}{|c|c|c|c|c|c|c|}
\hline & \multicolumn{6}{|c|}{ Period } \\
\hline & \multicolumn{2}{|c|}{ January } & \multicolumn{2}{|c|}{ April } & \multicolumn{2}{|c|}{ July } \\
\hline & 2005 & 2006 & 2005 & 2006 & 2005 & 2006 \\
\hline$G / R_{n}$ & 0.39 & 0.29 & 0.23 & 0.12 & 0.31 & 0.22 \\
\hline$H / R_{n}$ & 0.27 & 0.16 & 0.33 & 0.15 & 0.54 & 0.45 \\
\hline$\lambda E / R_{n}$ & 0.29 & 0.29 & 0.27 & 0.49 & 0.11 & 0.21 \\
\hline Maximum LAI & Very low & 1.3 & $<1$ & 2.5 & 0.1 & 0.35 \\
\hline$\theta_{\mathrm{v}}(\%)$ & 16.9 & 33.3 & 7.9 & 27.2 & 4.8 & 9.8 \\
\hline
\end{tabular}

\subsection{Seasonal and interannual variation in} evapotranspiration

The seasonal pattern of daily-integrated evapotranspiration $(E)$ is shown in Fig. 4a-c. To characterize the difference between the hydrological years of the study, we estimated the potential evapotranspiration $\left(E_{\mathrm{P}}\right)$, derived from Eq. (4), which represents the maximum expected evapotranspiration from a wet soil-plant surface. After the first rains in autumn, adequate soil moisture levels led to the germination of annuals and $E$ reached potential rates. Toward the spring a substantial difference in the temporal variation of $E$ was observed between the years as a result of the contrasting soil moisture conditions and LAI. There was a clear separation between $E$ and $E_{P}$ early in the winter of 2005. Nevertheless, in 2006, E proceeded at potential rates until the early spring (around DOY 120), when a maximum rate of $4.5 \mathrm{~mm}$ per day was achieved. The maximum daily rate $\left(2.8 \mathrm{~mm} \mathrm{~d}^{-1}\right)$ of 2005 was obtained around DOY 150 after a strong rain pulse, although, the rates were not significantly different $\left(2.3 \mathrm{~mm} \mathrm{~d}^{-1}\right)$ throughout the period of maximum LAI.

The maximum rate of evapotranspiration during the normal year (2005-2006) was similar to those recorded in a Mediterranean annual grassland in California (Baldocchi et al., 2004), in the 1998 growing season of a temperate grassland in Canada (Wever et al., 2002) and in a native tallgrass prairie in Oklahoma (Burba and Verma, 2005). On the other hand, Li et al. (2006) measured a maximum rate of $2.8 \mathrm{~mm}$ per day in a water stressed ecosystem, like the dry year (2004-2005).

After the senescence of the C3 species, which occurred by about mid-spring (12 May, DOY 132) in both hydrological years, distinct patterns of $E$ were identified. In late spring 2005, rain pulses propitiated short-term peaks in E. Afterwards, E 


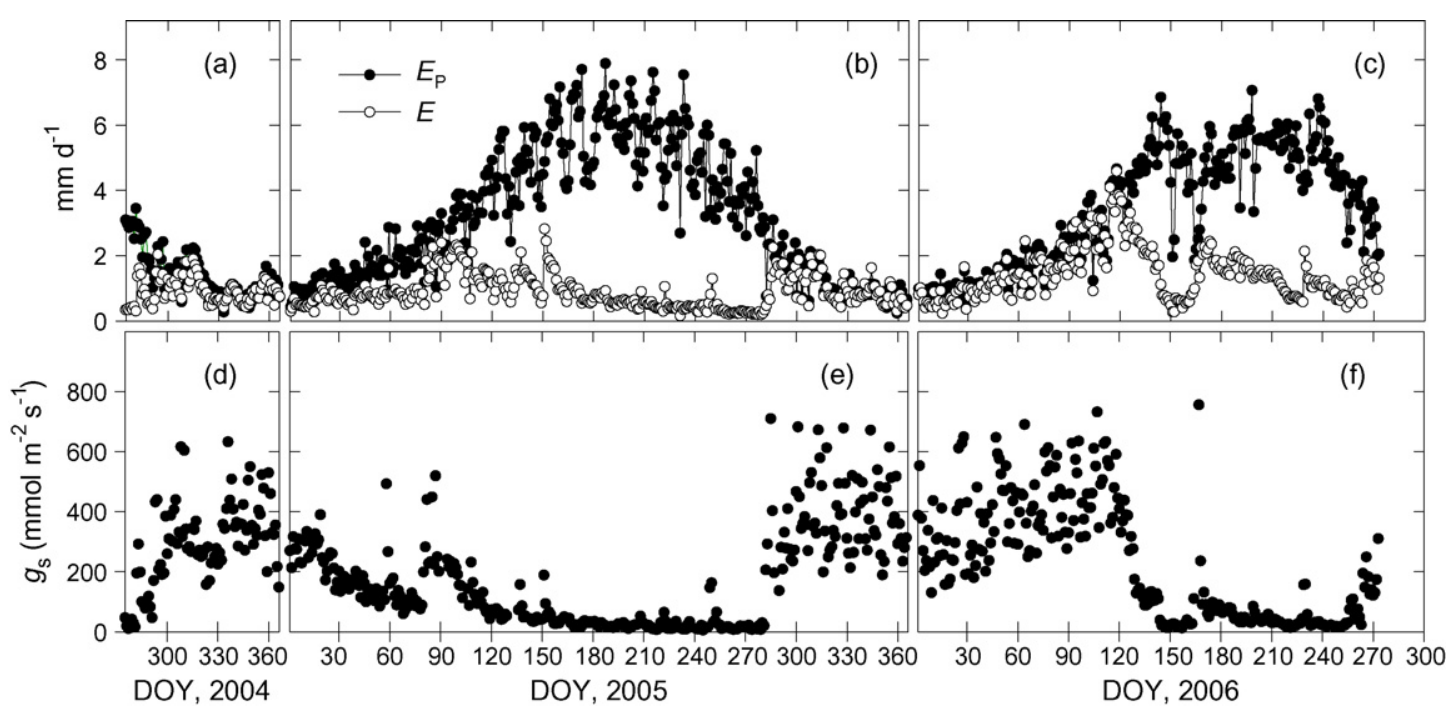

Fig. 4 - Seasonal variation in daily-integrated evapotranspiration $(E)$ and daily potential evapotranspiration $\left(E_{P}\right)$, $(a-c)$, and daily surface conductance $\left(g_{s}\right),(d-f)$, over the course of the study.

decreased smoothly toward the end of the summer, when LAI of the C4 grass was approaching zero. Although very low soil moisture levels ( $<5 \%$ in the top $15 \mathrm{~cm}$ of the soil), $E$ was well above $0.4 \mathrm{~mm}$ per day in mid summer and around $0.2 \mathrm{~mm}$ per day at the end of the summer. Given that the soil was very dry and compacted at the top, and with considerable amount of dead grass on it, we can speculate that soil evaporation would be very low. Thus, those low, but considerable rates of $E$, can be apparently explained by the physiological activity of the drought-tolerant C4 grass, C. dactylon, which has the ability to extend its roots deeply into the soil to enhance water absorption. The summer physiological activity is corroborated by the estimated photosynthetic rates, calculated using the method proposed by Reichstein et al. (2005), which varied from ca. $0.6 \mathrm{~g} \mathrm{C} \mathrm{m}^{-2}$ per day in mid summer to ca. $0.2 \mathrm{~g} \mathrm{C} \mathrm{m}^{-2}$ per day at the end of the summer. The daily water-use efficiencies (the ratio between the daily photosynthesis and the daily $E$ ) varied generally from 1.2 to $2 \mathrm{mmol} \mathrm{CO}_{2} \mathrm{~mol}^{-1} \mathrm{H}_{2} \mathrm{O}$ during the summer. In a previous study under Mediterranean conditions, Mamolos et al. (2001) also found that C. dactylon was active during the summer, even growing in the field at very low values of soil matric potential in the upper soil layer. In contrast to our results, Baldocchi et al. (2004) recorded daily rates of $E$ close to zero during the summer, in a Mediterranean annual grassland with absence of warm-season species.

In late spring 2006, the effects of grass cutting on $E$ were well evident between DOY 144 and 162. Since it reduced the LAI and the evapotranspiration was limited due to the dead grass left on the soil-plant surface, the daily rates were substantially reduced to around $0.5 \mathrm{~mm}$ per day (Fig. 4c). When the grass was finally removed, on DOY 162, subsequent strong rain events raised the soil moisture and the LAI of the C4 grass rapidly increased to 0.35 , leading to evapotranspiration rates of about $2 \mathrm{~mm}$ per day. Later, after DOY 213, the substantial reduction in $E$, from about 1.4 to $0.7 \mathrm{~mm}$ per day, resulted mainly from several grazing events that reduced the LAI of the C4 grass to 0.1 (Fig. 4c). Significant reductions in the daily $E$, due to reductions in transpiration by defoliation, have also been reported for a grazed prairie in Kansas, dominated by C4 grasses (Bremer et al., 2001). This occurrence provided, once more, a clear evidence of the relevant role of the warmseason C4 grass in controlling E during the summer. An increasing trend in $E$ during late summer was related to large rain events, which also promoted the emergence of C3 plants due to seed germination (Fig. 4c).

The contrasting seasonal and annual trends of $E$ were well supported by the variations in the estimated surface conductance $\left(g_{\mathrm{s}}\right)$ (Fig. 4d-f). Under well-watered conditions, $g_{\mathrm{s}}$ reached maximum values and $E$ occurred at near potential rates, but with significant day-to-day variation (200$600 \mathrm{mmol} \mathrm{m}^{-2} \mathrm{~s}^{-1}$ ). This variation reflected the measurements from dry or wet surfaces and under cloudy or sunny days (Baldocchi et al., 2004). In contrast, when soil moisture was not adequate to sustain evapotranspiration at potential rates, $g_{\mathrm{s}}$ decreased, showing a less day-to-day variation and reaching minimum values (of about $10 \mathrm{mmol} \mathrm{m}^{-2} \mathrm{~s}^{-1}$ ) in the summer of both years. However, during the summer of $2006, g_{\mathrm{s}}$ was generally higher that in the previous summer due to greater soil moisture and higher LAI. The mean $g_{\mathrm{s}}$ values for different periods of growth of both hydrological years are shown in Table 1.

Fig. 5 shows the cumulative evapotranspiration and precipitation for both hydrological years. For the dry year (2004-2005), cumulative E and precipitation were 316 and $364 \mathrm{~mm}$, respectively. During the normal year (2005-2006), E and precipitation amounted respectively to 481 and $751 \mathrm{~mm}$. In Table 1, we show the budgets and the water balances (E/PPT) for the three selected periods of growth, as well as the annual values for both hydrological years. During the Dry period, E was $31 \%$ and $37 \%$ of the annual evapotranspiration of the first and the second hydrological years, respectively. The accumulated $E$ for the dry year is close to the annual sums reported for an Mediterranean annual grassland in California (Baldocchi et al., 2004), but higher than the annual evapotranspiration 


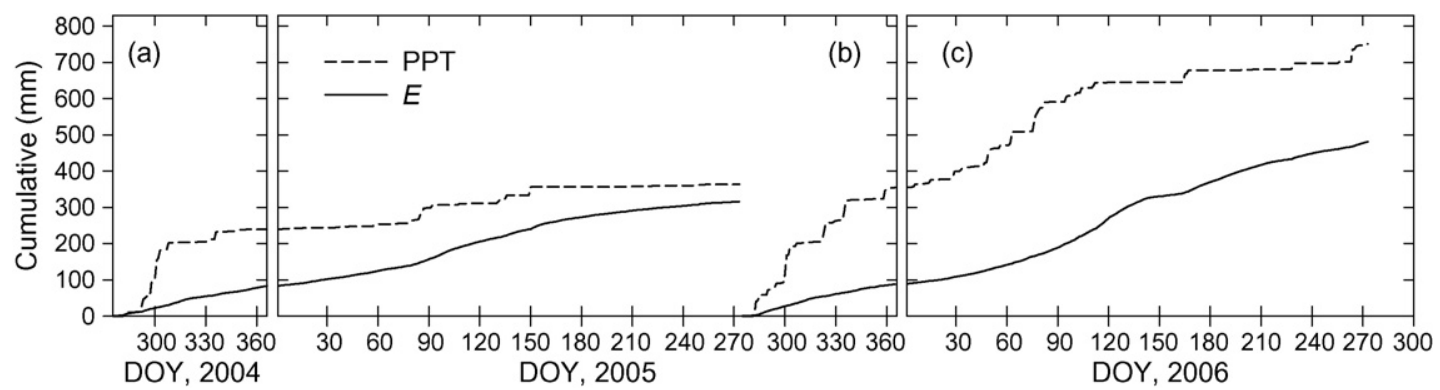

Fig. 5 - Cumulative precipitation (PPT) and evapotranspiration (E) for (a and b) the 2004-2005 hydrological year and (b and c) the 2005-2006 hydrological year.

measured in other grasslands ecosystems (Wever et al., 2002; Li et al., 2006). Much higher amounts of annual evapotranspiration, even relatively to our normal year, were reported for native tallgrass prairies in the summer rain monsoon climate of North America (Burba and Verma, 2001, 2005).

We found a large difference in the annual water balances between years (Fig. 5, Table 1). Although, negative annual balances were observed in both hydrological years, in the dry year $E$ was $87 \%$ of the precipitation and only $64 \%$ in the normal year. The better closure in the dry year may be attributed to lower losses by runoff. Furthermore, a long period with soil at field capacity during the normal year may have increased the water infiltration into the soil, where it may have percolated to the water table (Law et al., 2002).

Despite negative annual balances, the Growth period of the 2004-2005 hydrological year and the Dry periods of both years, had positive balances (Table 1). The highest balance (2.40) was attained in the Dry period of 2005. In the Dry period of 2006, the balance was considerably lower (1.68), mainly due to the large inputs of water at the end of that period that in practice were not evapotranspired within the period. Excluding that period of rain, the balance becomes similar to that in the Dry period of 2005. Based on these results, here we can highlight, once more, the role of the warm-season C4 grass after the senescence of the C3 species. For example, the difference between $E$ and precipitation in the Dry period of 2005 was about $57 \mathrm{~mm}$ (Table 1), which means that the soil lost an extra $57 \mathrm{~mm}$ of water. The same exercise for the Dry period of 2006 yielded $72 \mathrm{~mm}$, but excluding from the analysis the rain at the end of the Dry period that was not evapotranspired, results in ca. $112 \mathrm{~mm}$. As we mention above, we believe that this soil had very low evaporation during the Dry period. Thus, we may speculate that those extra losses, equivalent to $18 \%$ and $23 \%$ of the total $E$ of the dry and normal years, respectively, were largely related to the water extracted by the deep-rooted C. dactylon. Even if we consider a possible overestimation or underestimation of evapotranspiration, in the order of the energy imbalance observed, the essence of this exercise would not be significantly altered.

\subsection{Biophysical controls on surface conductance and evapotranspiration}

\subsubsection{Effects of soil moisture}

To determine the soil moisture threshold below which evapotranspiration is affected, we assessed the relationship between the Priestley-Taylor coefficient and the volumetric soil moisture content, using an approach similar to Baldocchi et al. (2004) (see Fig. 6c and d). Under well-watered conditions, $\lambda E / \lambda E_{\text {eq }}$ varied from 0.9 to around 1.2 (close to the PriestleyTaylor constant, 1.26), but declined substantially when volumetric soil moisture content dropped below 14\% and 13\% in the 2004-2005 and 2005-2006 hydrological years, respectively. The surface conductance (Fig. $6 a$ and b) also showed a similar trend.

Since the results were similar for both hydrological years, we assumed, from a conservative point of view, a critical $\theta_{\mathrm{v}}$ of $14 \%$ for this grassland. This critical $\theta_{\mathrm{v}}$ agrees reasonably well with that $(13 \%)$ reported for the Mediterranean annual grassland in California (Baldocchi et al., 2004). Similarly, Hunt et al. (2002) found that the evaporative fraction of a tussock grassland, in New Zealand, declined sharply when soil moisture dropped below the threshold of $12 \%$. However, while Baldocchi et al. (2004) found that $\lambda E / \lambda E_{\text {eq }}$ decreased precipitously below the critical $\theta_{\mathrm{v}}$, we observed a gradual decrease, similar to that observed in the tussock grassland. This suggests that the physiological activity of the warmseason C4 grass may have attenuated the decreases in evapotranspiration during and after the senescence of the C3 species. In addition, the significant rates of evapotranspiration observed during the summer periods explain the relatively high ratios of $\lambda E / \lambda E_{\text {eq }}$ at the $\theta_{\mathrm{v}}$ lowest levels.

In the 2005-2006 hydrological year, the lowest values of $\lambda E /$ $\lambda E_{\text {eq }}$ and $g_{\mathrm{s}}$ were measured after grass cutting, when the grass was left covering partially the soil-plant surface (Fig. $6 \mathrm{~b}$ and d). The period after the heavy summer rain, in 2006, is also shown in Fig. $6 \mathrm{~b}$ and $d$. In general, $\lambda E / \lambda E_{\text {eq }}$ and $g_{\mathrm{s}}$ declined with the gradual decrease in soil moisture after the heavy rain event. However, the ratios of $\lambda E / \lambda E_{\text {eq }}$ increased when the soil moisture levels approached $13 \%$. This was the result of a long period with cloudy conditions that reduced $\lambda E_{\text {eq }}$, while $\lambda E$ remained fairly unchanged.

\subsubsection{Effects of canopy development}

The dependence of surface conductance and/or evapotranspiration on canopy development has been observed in numerous studies across the world (Kelliher et al., 1993; Rosset et al., 1997; Saigusa et al., 1998; Burba and Verma, 2005; Li et al., 2006). In this study, we found a strong linear correlation between the evaporative fraction and the leaf area index (Fig. 7), under abundant soil moisture and dense 

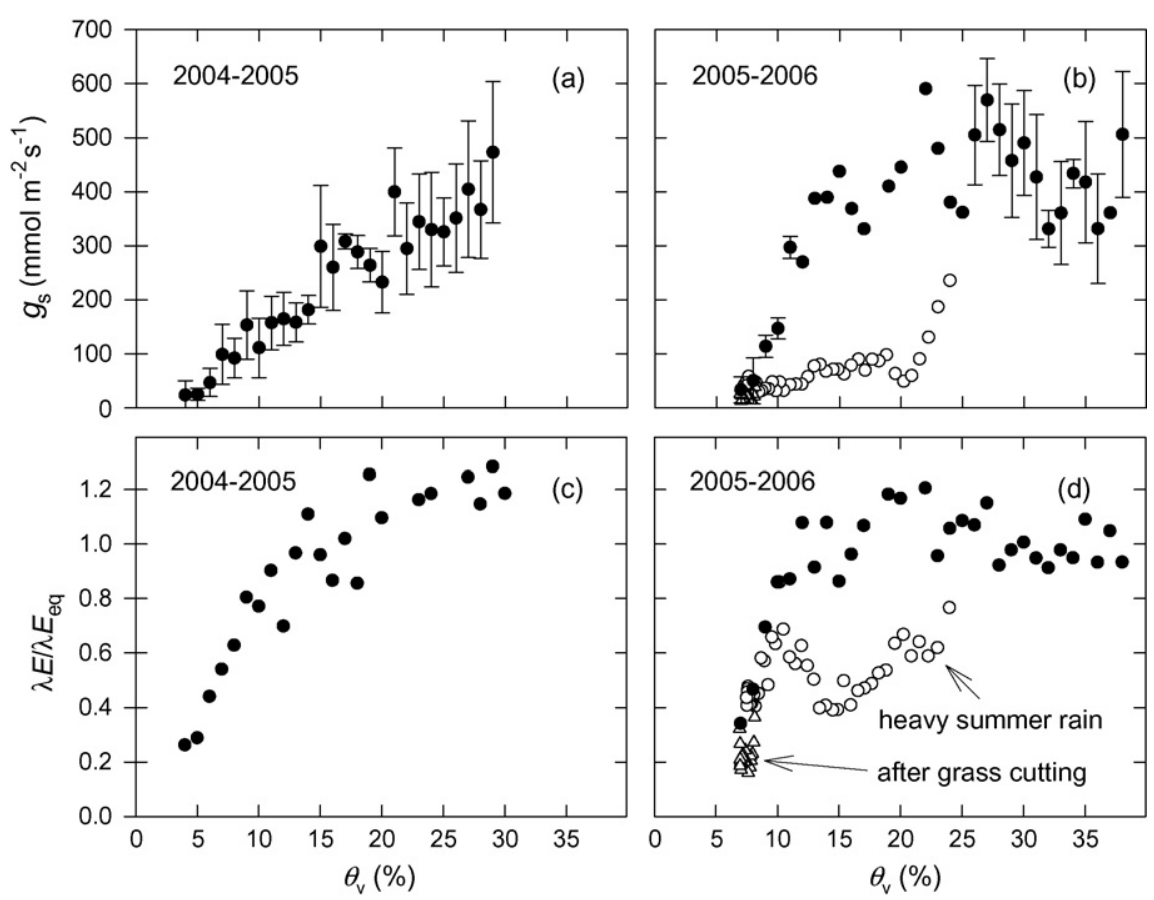

Fig. 6 - (a and b) surface conductance $\left(g_{s}\right)$ and (c and d) Priestley-Taylor coefficient $\left(\lambda E / \lambda E_{\text {eq }}\right)$ in relation to volumetric soil moisture content $\left(\theta_{v}\right)$, averaged from the upper $15 \mathrm{~cm}$ of soil (the most important layer for C3 species roots), for the 20042005 and 2005-2006 hydrological years. Daily values of $g_{\mathrm{s}}$ and $\lambda E / \lambda E_{\text {eq }}$ were bin-averaged into $1 \%$ bins (black circles).

Vertical bars represent the standard error. Daily values for the period after grass cutting (triangle up), where the grass was left covering partially the terrain, and the period after the heavy summer rain (white circles), in 2006, are also shown.

vegetation (LAI $>1$ ). The changes in LAI explained $73 \%$ of the variance found in $\lambda E / R_{n}(P<0.01)$. The importance of LAI in controlling the evaporative fractions, under abundant soil moisture, was also well evident $\left(R^{2}=0.58\right)$ in a native tallgrass prairie in Oklahoma (Burba and Verma, 2005).

Under well-watered conditions, but when LAI was less than 1 (vegetation height less than $3 \mathrm{~cm}$ ), the evaporative fractions were relatively high (not shown). This may be explained by a large contribution of soil evaporation and a presence of a

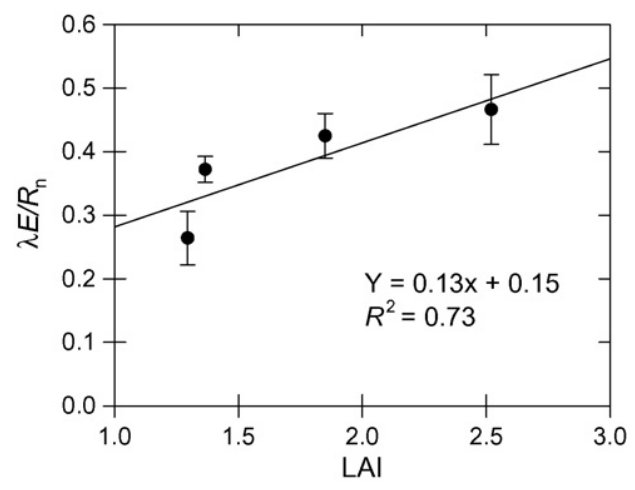

Fig. 7 - Relationship between mean daytime evaporative fraction $\left(\lambda E / R_{n}\right)$ and leaf area index (LAI) for the 2005-2006 hydrological year, when the vegetation was dense (LAI > 1). Data represent 5-day averages ( \pm S.E.) around the LAI measurement days. canopy with a great proportion of young leaves with lower stomatal resistance (Rosset et al., 1997).

In this study, we could not observe a clear influence of changes in LAI on surface conductance because of a large dayto-day variation. In fact, this problem has also been found in the study of other Mediterranean grassland (Baldocchi et al., 2004).

\subsubsection{Effects of vapour pressure deficit}

Fig. 8 illustrates the dependence of surface conductance on vapour pressure deficit in the two years of the study. It is evident that as soon as $D$ increased, $g_{\mathrm{s}}$ became limited. However, the sensitivity of these responses is mainly affected by the soil moisture conditions. A close inspection shows that for $\mathrm{D}<0.5 \mathrm{kPa}$ there was no distinct effect on surface conductance because of the well-watered conditions and hence a large dayto-day variation in $g_{s}$. This implies that in ecosystems such as this, $D$ plays a stronger role in controlling $g_{\mathrm{s}}$ when the soil moisture is not adequate, than otherwise. To examine this, we assessed the relationship between $g_{\mathrm{s}}$ and $D$ for short periods under limiting soil moisture conditions, when volumetric soil moisture content was nearly constant (Fig. 9). For all the cases, it was found that more than $78 \%$ of the variance in $g_{\mathrm{s}}$ was explained by the changes in $D(P<0.0001)$. Considering the consequences of summer drought, David et al. (2004) also reported a strong linear relationship between midday canopy resistance and $D$ for an evergreen oak tree near Évora, Portugal.

To quantify the relative importance of $D$ in controlling the evapotranspiration on a daily and seasonal basis, we 

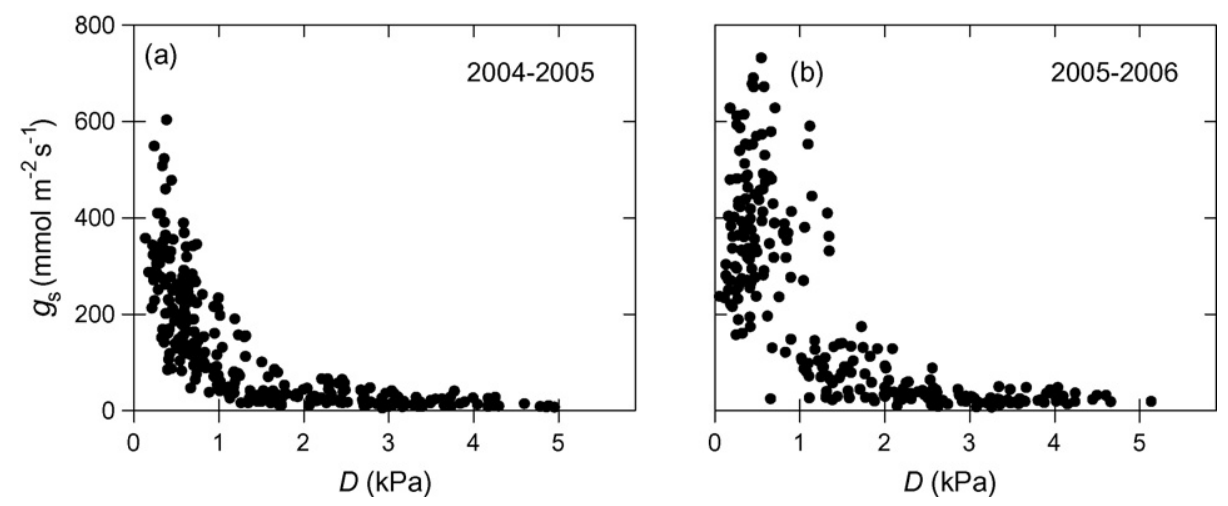

Fig. 8 - Relationship between daily (daytime average) surface conductance $\left(g_{s}\right)$ and mean daytime vapour pressure deficit (D) for (a) the 2004-2005 hydrological year and (b) the 2005-2006 hydrological year. Periods of rain were excluded from the analysis.
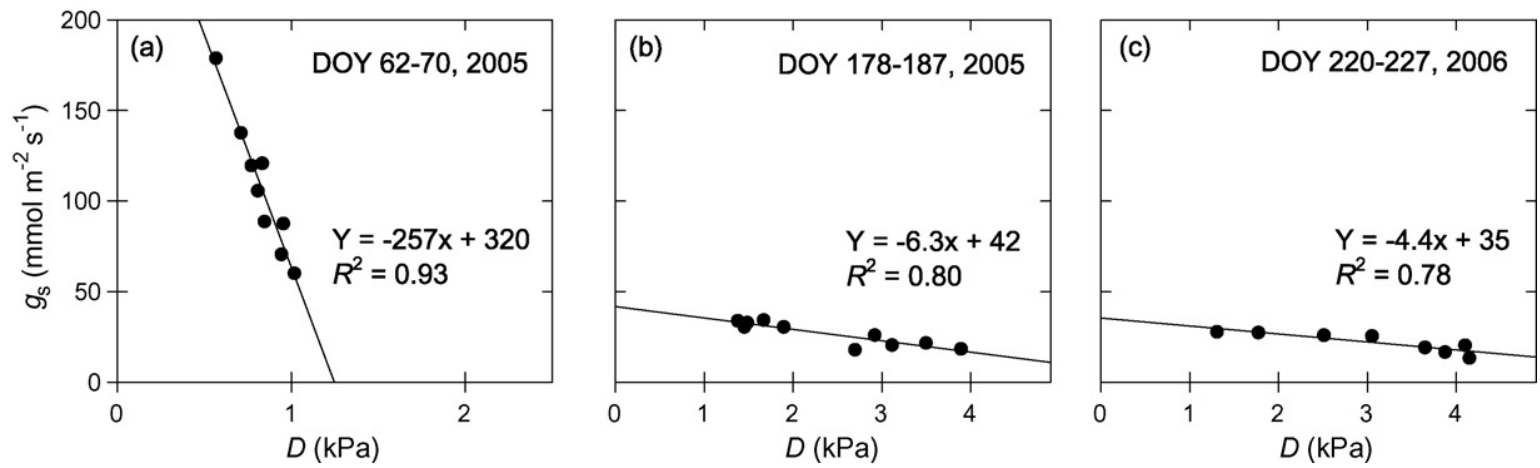

Fig. 9 - Relationship between daily (daytime average) surface conductance $\left(g_{s}\right)$ and mean daytime vapour pressure deficit (D) for short periods (8-10 days) under limiting soil moisture conditions, when volumetric soil moisture content was nearly constant. Shown are the examples of (a) the period of severe drought conditions during the late winter 2005 (DOY 62-70), (b) the summer 2005 (DOY 178-187) and (c) the summer 2006 (DOY 220-227).

determined the decoupling coefficient $(\Omega)$ (Jarvis and McNaughton, 1986). This coefficient varies from 0 to 1 ; when it approaches 0 , the ecosystem surface and the atmosphere are aerodynamically coupled and the evapotranspiration proceeds at rates imposed by $D$ and $g_{s}$; when it approaches 1 the ecosystem surface and the atmosphere are aerodynamically decoupled and the evapotranspiration is controlled by the available energy.

On a seasonal basis, the daily values of $\Omega$ varied from a maximum of about 0.7 , under ample soil moisture and low $D$, to a minimum of 0.05 and 0.1 during the summers of 2005 and
2006, respectively (Fig. 10). These low values of $\Omega$ indicate a strong control of evapotranspiration by $D$ and $g_{s}$. In contrast, during the wet periods the available energy was the main driver of evapotranspiration, but $D$ was still reasonably high. Consistent with our study, Valentini et al. (1995) reported that $\Omega$ of a Mediterranean annual grassland varied from 0.8 , early in the growing season, to 0.1 as the soil moisture decreased. In Table 1 it is presented the mean $\Omega$ values at different periods of growth for both hydrological years.

The diurnal pattern of $\Omega$ and $g_{\mathrm{s}}$ showed a distinct seasonal and interannual variation (Fig. 11). As an example, we selected

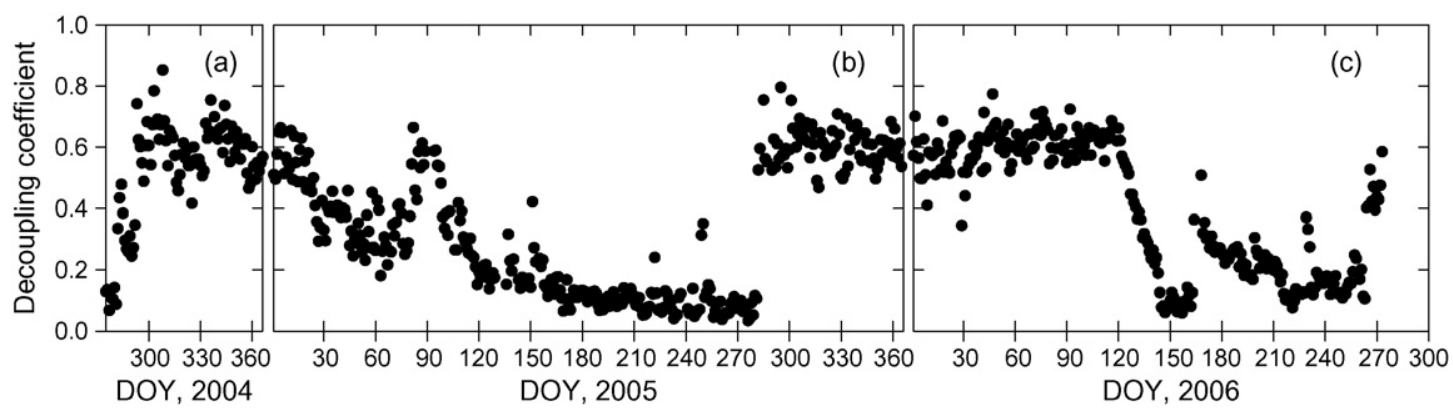

Fig. 10 - Seasonal variation in daily (daytime average) decoupling coefficient $(\Omega)$ over the course of the study (a-c). 

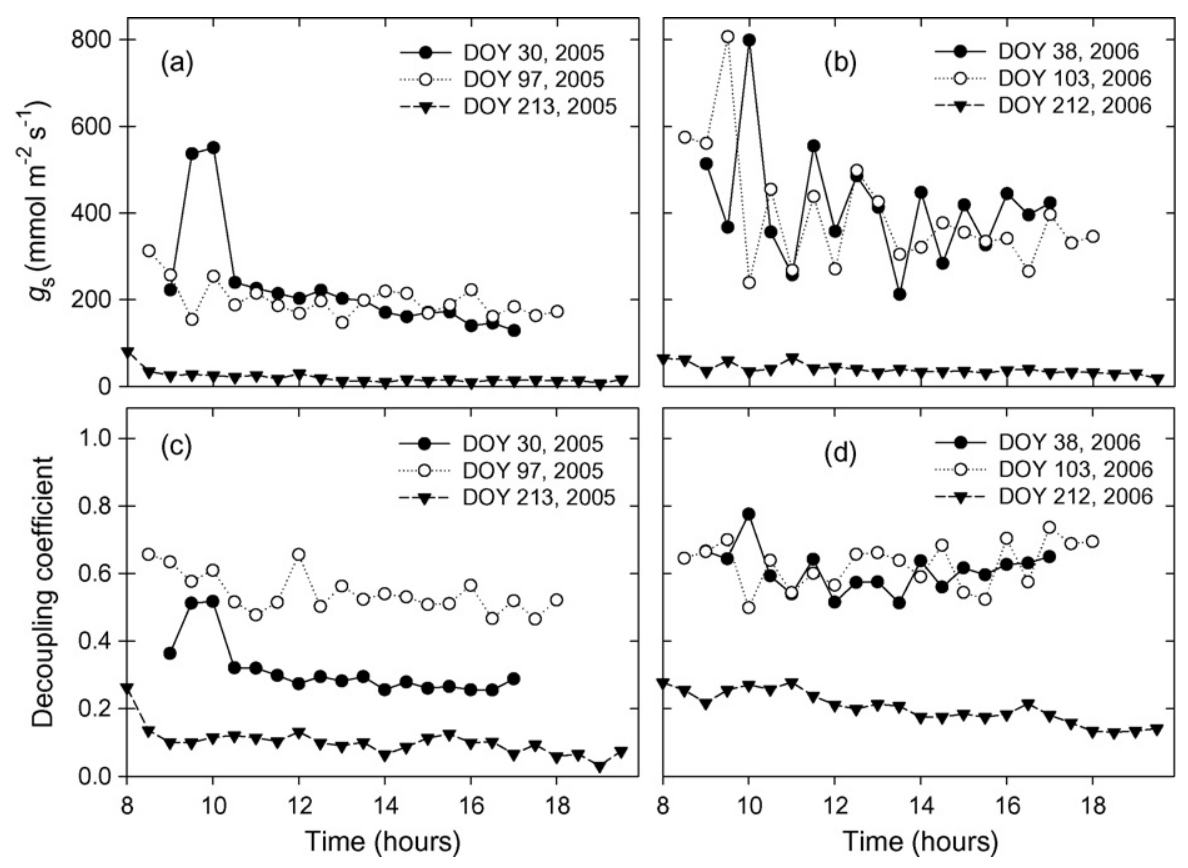

Fig. 11 - Seasonal and interannual variation in diurnal pattern of surface conductance $\left(g_{\mathrm{s}}\right)$, (a and b), and decoupling coefficient $(\Omega)$, (c and d), on typical cloudless or near-cloudless days. The figure shows periods with short vegetation and low evapotranspiration (DOY 30, 2005 and DOY 38, 2006), periods near the maximum LAI and evapotranspiration (DOY 97, 2005 and DOY 103, 2006) and summer periods where only the C4 species was present (DOY 213, 2005 and DOY 212, 2006). UTC time was used.

typical days of periods with short vegetation and low E (DOY 30, 2005 and DOY 38, 2006), periods near the maximum LAI and $E$ (DOY 97, 2005 and DOY 103, 2006) and summer periods where only the warm-season C4 species was present (DOY 213, 2005 and DOY 212, 2006). Overall, the diurnal pattern of $\Omega$ and $g_{\mathrm{s}}$ was similar. In 2006, $\Omega$ remained fairly constant through the day on DOY 38 and 103, indicating that water was available in the soil. In contrast, on DOY 30 and 97 of 2005, $\Omega$ decreased as the day progressed, revealing an increasing control of $D$ and $g_{\text {s }}$ on $E$. This suggests that, under soil moisture deficits, the plants reduced the stomatal conductance during the afternoon in response to high temperatures and $D$, preventing excessive losses of water, as commonly reported (e.g., Verhoef et al., 1996; Loustau et al., 1996).

On DOY 97 of 2005, $\Omega$ was considerably high due to the relatively high soil moisture that resulted from previous late winter rainfall. However, a few days afterwards, $\Omega$ was substantially lower, showing a stronger decreasing trend as the day progressed. The peaking values of $\Omega$ and $g_{\mathrm{s}}$, early in the morning, suggest evaporation of dew (Gu et al., 2005). In the summer periods (DOY 213, 2005 and DOY 212, 2006) the decreasing trend from the morning to the afternoon was also evident. This decreasing trend was observed in other ecosystems (Wever et al., 2002; Gu et al., 2005).

\section{Conclusions}

The observation of two climatologically contrasting hydrological years (one dry, 2004-2005, and another normal, 20052006) offered a unique opportunity to understand how interannual climate variability, namely drought, affects the energy and water vapour exchange between a grassland and the atmosphere under a Mediterranean climate. The seasonal and interannual variation in energy partitioning was primarily controlled by soil water availability and canopy growth. In the dry year, the drought in winter and early spring limited the grass production, and as a consequence of these conditions most of the annual $R_{n}$ was consumed in $H$, as would be the case in a semi-arid climate. In contrast, $\lambda E$ dominated the annual energy partitioning in the normal year. Although, on an annual basis $G$ consumed a minor part of $R_{n}$, we found that during daytime it played a stronger role, even dominating the energy partitioning in periods with short grass and low soil temperatures.

During the winter and early spring periods of the normal year, E proceeded at potential rates and reached a maximum rate twice as high as the rate recorded in the dry year, when $E$ remained clearly below the potential rate. Between the end of the senescence of the $\mathrm{C} 3$ annual grasses, in mid-spring, and the early autumn, the warm-season C4 grass, C. dactylon L., played a preponderant role in maintaining substantial rates of E. We estimated that the presence of this C4 grass, during that period, contributed to an additional $E$ probably equivalent to around $18 \%$ and $23 \%$ of the total $E$ of the dry and normal years, respectively, thus greatly contributing for soil water depletion. However, further investigation is needed in order to better understand the role of this invasive species during the summer. For example, measurements of leaf stomatal conductance, maximum depth of its roots and soil water content for the entire soil profile, would be valuable inputs of information. 
The evapotranspiration of the grassland was primarily affected by the soil water availability. We found that whenever the average volumetric soil moisture content in the top $15 \mathrm{~cm}$ of the soil profile dropped below 14\%, the Priestley-Taylor coefficient and surface conductance were substantially reduced. Under these conditions, the evapotranspiration did not proceed at potential rates. Thus, this critical value can be empirically used to indicate whether or not the soil moisture is a limiting factor. When soil moisture was not limiting, the long-term changes in the evaporative fractions were mainly explained by changes in LAI (when LAI $>1$ ) and the daily rates of $E$ were predominantly controlled by the available energy. As soon as soil moisture became limiting, E was strongly controlled by the vapour pressure deficit and surface conductance.

\section{Acknowledgments}

The authors thank "Fundação para a Ciência e a Tecnologia" for financial support through a Ph.D. grant to L.M. Aires. This work was performed under the CARBOEUROPE-IP European Project financed by the European Community.

\section{R E F E R E N C E S}

Adams, J.M., Faure, H., Fauredenard, L., Mcglade, J.M., Woodward, F.I., 1990. Increases in terrestrial carbon storage from the last glacial maximum to the present. Nature 348, 711-714.

Allen, R.G., Pereira, L.S., Raes, D., Smith, M., 1998. Crop evapotranspiration: guidelines for computing crop water requirements. FAO Irrigation and drainage Paper 56. FAO, Rome, Italy, $300 \mathrm{pp}$.

Baldocchi, D.D., Xu, L.K., Kiang, N., 2004. How plant functionaltype, weather, seasonal drought, and soil physical properties alter water and energy fluxes of an oak-grass savanna and an annual grassland. Agric. For. Meteorol. 123, 13-39.

Bremer, D.J., Auen, L.M., Ham, J.M., Owensby, C.E., 2001. Evapotranspiration in a prairie ecosystem: effects of grazing by cattle. Agron. J. 93, 338-348.

Burba, G.G., Verma, S.B., 2001. Prairie growth, PAR albedo and seasonal distribution of energy fluxes. Agric. For. Meteorol. 107, 227-240.

Burba, G.G., Verma, S.B., 2005. Seasonal and interannual variability in evapotranspiration of native tallgrass prairie and cultivated wheat ecosystems. Agric. For. Meteorol. 135, 190-201.

David, T.S., Ferreira, M.I., Cohen, S., Pereira, J.S., David, J.S., 2004. Constraints on transpiration from an evergreen oak tree in southern Portugal. Agric. For. Meteorol. 122, 193-205.

Falge, E., Baldocchi, D., Olson, R., Anthoni, P., Aubinet, M., Bernhofer, C., Burba, G., Ceulemans, G., Clement, R., Dolman, H., Granier, A., Gross, P., Grunwald, T., Hollinger, D., Jensen, N.O., Katul, G., Keronen, P., Kowalski, A., Lai, C.T., Law, B.E., Meyers, T., Moncrieff, J., Moors, E., Munger, J.W., Pilegaard, K., Rannik, U., Rebmann, C., Suyker, A., Tenhunen, J., Tu, K., Verma, S., Vesala, T., Wilson, K., Wofsy, S., 2001. Gap filling strategies for long term energy flux data sets. Agric. For. Meteorol. 107, 71-77.
Foken, T., Wichura, B., 1996. Tools for quality assessment of surface-based flux measurements. Agric. For. Meteorol. 78, 83-105.

Fuehrer, P.L., Friehe, C.A., 2002. Flux corrections revisited. Bound. Layer Meteorol. 102, 415-457.

Gockede, M., Markkanen, T., Hasager, C.B., Foken, T., 2006. Update of a footprint-based approach for the characterisation of complex measurement sites. Bound. Layer Meteorol. 118, 635-655.

Gu, S., Tang, Y.H., Cui, X.Y., Kato, T., Du, M.Y., Li, Y.N., Zhao, X.Q., 2005. Energy exchange between the atmosphere and a meadow ecosystem on the Qinghai-Tibetan Plateau. Agric. For. Meteorol. 129, 175-185.

Huang, B., Duncan, R.R., Carrow, R.N., 1997. Drought-resistance mechanisms of seven warm-season turfgrasses under surface soil drying. 1. Shoot response. Crop Sci. 37, 1858-1863.

Hunt, J.E., Kelliher, F.M., McSeveny, T.M., Byers, J.N., 2002. Evaporation and carbon dioxide exchange between the atmosphere and a tussock grassland during a summer drought. Agric. For. Meteorol. 111, 65-82.

INMG, 1991. O Clima de Portugal. Normais climatológicas da região de Alentejo e Algarve, correspondentes a 1951-1980, Fascículo XLIX, vol. 4-4a região. Instituto Nacional de Meteorologia e Geofísica, Lisboa, Portugal, 98 pp.

Jarvis, P.G., McNaughton, K.G., 1986. Stomatal control of transpiration - scaling up from leaf to region. Adv. Ecol. Res. $15,1-49$

Kato, T., Tang, Y.H., Gu, S., Cui, X.Y., Hirota, M., Du, M.Y., Li, Y.N., Zhao, Z.Q., Oikawa, T., 2004. Carbon dioxide exchange between the atmosphere and an alpine meadow ecosystem on the Qinghai-Tibetan Plateau, China. Agric. For. Meteorol. 124, 121-134.

Kelliher, F.M., Leuning, R., Schulze, E.D., 1993. Evaporation and canopy characteristics of coniferous forests and grasslands. Oecologia 95, 153-163.

Law, B.E., Falge, E., Gu, L., Baldocchi, D.D., Bakwin, P., Berbigier, P., Davis, K., Dolman, A.J., Falk, M., Fuentes, J.D., Goldstein, A., Granier, A., Grelle, A., Hollinger, D., Janssens, I.A., Jarvis, P., Jensen, N.O., Katul, G., Mahli, Y., Matteucci, G., Meyers, T., Monson, R., Munger, W., Oechel, W., Olson, R., Pilegaard, K., Paw, K.T., Thorgeirsson, H., Valentini, R., Verma, S., Vesala, T., Wilson, K., Wofsy, S., 2002. Environmental controls over carbon dioxide and water vapor exchange of terrestrial vegetation. Agric. For. Meteorol. 113, 97-120.

Li, S.G., Eugster, W., Asanuma, J., Kotani, A., Davaa, G., Oyunbaatar, D., Sugita, M., 2006. Energy partitioning and its biophysical controls above a grazing steppe in central Mongolia. Agric. For. Meteorol. 137, 89-106.

Liu, H.P., Peters, G., Foken, T., 2001. New equations for sonic temperature variance and buoyancy heat flux with an omnidirectional sonic anemometer. Bound. Layer Meteorol. $100,459-468$.

Loustau, D., Berbigier, P., Roumagnac, P., ArrudaPacheco, C., David, J.S., Ferreira, M.I., Pereira, J.S., Tavares, R., 1996. Transpiration of a 64-year-old maritime pine stand in Portugal. 1. Seasonal course of water flux through maritime pine. Oecologia 107, 33-42.

Mamolos, A.P., Veresoglou, D.S., Noitsakis, V., Gerakis, A., 2001. Differential drought tolerance of five coexisting plant species in Mediterranean lowland grasslands. J. Arid Environ. 49, 329-341.

Meyers, T.P., 2001. A comparison of summertime water and $\mathrm{CO}_{2}$ fluxes over rangeland for well watered and drought conditions. Agric. For. Meteorol. 106, 205-214.

Miranda, P.M.A., Coelho, F.E.S., Tomé, A.R., Valente, M.A., Carvalho, A., Pires, C., Pires, H.O., Pires, V.C., Ramalho, C., 2002. 20th century portuguese climate and climate scenarios. In: Santos, F.D., Forbes, K., Moita, R. (Eds.), 
Climate Change in Portugal: Scenarios. Impacts and Adaptation Measures (SIAM Project), Gradiva, pp. 23-83.

Monteith, J.L., 1965. Evaporation and environment. In: Fogg, G.E. (Ed.), The State and Movement of Water in Living Organisms. Academic Press, New York, pp. 205-234.

Monteith, J.L., Unsworth, M.H., 1990. Principles of Environmental Physics, second ed. Chapman and Hall, New York, USA.

Pereira, J.S., Mateus, J.A., Aires, L.M., Pita, G., Pio, C., David, J.S., Andrade, V., Banza, J., David, T.S., Paço, T.A., Rodrigues, A., 2007. Net ecosystem carbon exchange in three contrasting Mediterranean ecosystems. The effect of drought. Biogeosciences 4, 791-802.

Priestley, C.H.B., Taylor, R.J., 1972. On the assessment of surface heat flux and evaporation using large-scale parameters. Monthly Weather Rev. 100, 81-92.

Rannik, U., Markkanen, T., Raittila, J., Hari, P., Vesala, T., 2003. Turbulence statistics inside and over forest: influence on footprint prediction. Bound. Layer Meteorol. 109, 163-189.

Raupach, M.R., 1998. Influences of local feedbacks on land-air exchanges of energy and carbon. Global Change Biol. 4, 477494.

Reichstein, M., Falge, E., Baldocchi, D., Papale, D., Aubinet, M., Berbigier, P., Bernhofer, C., Buchmann, N., Gilmanov, T., Granier, A., Grunwald, T., Havrankova, K., Ilvesniemi, H., Janous, D., Knohl, A., Laurila, T., Lohila, A., Loustau, D., Matteucci, G., Meyers, T., Miglietta, F., Ourcival, J.M., Pumpanen, J., Rambal, S., Rotenberg, E., Sanz, M., Tenhunen, J., Seufert, G., Vaccari, F., Vesala, T., Yakir, D., Valentini, R., 2005. On the separation of net ecosystem exchange into assimilation and ecosystem respiration: review and improved algorithm. Global Change Biol. 11, 1424-1439.

Rogiers, N., Eugster, W., Furger, M., Siegwolf, R., 2005. Effect of land management on ecosystem carbon fluxes at a subalpine grassland site in the Swiss Alps. Theor. Appl. Climatol. 80, 187-203.

Rosset, M., Riedo, M., Grub, A., Geissmann, M., Fuhrer, J., 1997. Seasonal variation in radiation and energy balances of permanent pastures at different altitudes. Agric. For. Meteorol. 86, 245-258.

Saigusa, N., Oikawa, T., Liu, S., 1998. Seasonal variations of the exchange of $\mathrm{CO}_{2}$ and $\mathrm{H}_{2} \mathrm{O}$ between a grassland and the atmosphere: an experimental study. Agric. For. Meteorol. 89, 131-139.

Twine, T.E., Kustas, W.P., Norman, J.M., Cook, D.R., Houser, P.R., Meyers, T.P., Prueger, J.H., Starks, P.J., Wesely, M.L., 2000. Correcting eddy-covariance flux underestimates over a grassland. Agric. For. Meteorol. 103, 279-300.

Valentini, R., Gamon, J.A., Field, C.B., 1995. Ecosystem gasexchange in a California grassland - seasonal patterns and implications for scaling. Ecology 76, 1940-1952.

van der Molen, M.K., Gash, J.H.C., Elbers, J.A., 2004. Sonic anemometer (co)sine response and flux measurement-II. The effect of introducing an angle of attack dependent calibration. Agric. For. Meteorol. 122, 95-109.

Verhoef, A., Allen, S.J., DeBruin, H.A.R., Jacobs, C.M.J., Heusinkveld, B.G., 1996. Fluxes of carbon dioxide and water vapour from a Sahelian savanna. Agric. For. Meteorol. 80, 231-248.

Vickers, D., Mahrt, L., 1997. Quality control and flux sampling problems for tower and aircraft data. J. Atmos. Oceanic Technol. 14, 512-526.

Vignolio, O.R., Biel, C., de Herralde, F., Araujo-Alves, J.P.L., Save, R., 2002. Growth of Lotus creticus creticus and Cynodon dactylon under two levels of irrigation. Aust. J. Agric. Res. 53, 13751381.

Vignolio, O.R., Biel, C., de Herralde, F., Araujo-Alves, J.P.L., Save, R., 2005. Use of water-stress tolerant Lotus creticus and Cynodon dactylon in soil revegetation on different slopes in a Mediterranean climate. Ann. Bot. Fenn. 42, 195-205.

Webb, E.K., Pearman, G.I., Leuning, R., 1980. Correction of flux measurements for density effects due to heat and watervapor transfer. Quart. J. Roy. Meteorol. Soc. 106, 85-100.

Wever, L.A., Flanagan, L.B., Carlson, P.J., 2002. Seasonal and interannual variation in evapotranspiration, energy balance and surface conductance in a northern temperate grassland. Agric. For. Meteorol. 112, 31-49.

Wilson, K., Goldstein, A., Falge, E., Aubinet, M., Baldocchi, D., Berbigier, P., Bernhofer, C., Ceulemans, R., Dolman, H., Field, C., Grelle, A., Ibrom, A., Law, B.E., Kowalski, A., Meyers, T., Moncrieff, J., Monson, R., Oechel, W., Tenhunen, J., Valentini, R., Verma, S., 2002. Energy balance closure at FLUXNET sites. Agric. For. Meteorol. 113, 223-243.

Zeng, N., Neelin, J.D., 2000. The role of vegetation-climate interaction and interannual variability in shaping the African savanna. J. Clim. 13, 2665-2670. 